\title{
ULUSLARARASI SISTEMDE ÜLKELERİN ELLE TUTULAMAYAN RAKİP İLE MÜCADELESİ: ULUSLARARASI GÜVENLİK AÇISINDAN KÜRESEL ISINMA PROBLEMI
}

\author{
THE STRUGGLE OF COUNTRIES WITH THE INTANGIBLE CHALLENGER IN THE \\ INTERNATIONAL SYSTEM: GLOBAL WARMING PROBLEM IN TERMS OF \\ INTERNATIONAL SECURITY
}

\author{
Bülend Aydın ERTEKİN ${ }^{1}$
}

\section{$\ddot{\mathbf{O} z}$}

$\mathrm{Bu}$ çalışmada, küresel ısınmaya bağlı tüm olumsuzlukların, uluslararası boyutta insan yaşamı güvenliğini tehdit etmesi üzerinde durulmaktadır. Küresel 1sınma insanın, ülkelerin ve dolayısıyla ulus-devletlerin çevre kapsamında ele alınan bir güvenlik sorununu teşkil etmektedir. Ancak çevre kavramı kapsamında "masum" gözüken bu tehdit aynı zamanda, bölgesel ve uluslararası krizlerin de arka plandaki tetikleyicisi olabilmektedir. Bu bağlamda, bu çalışmada, küresel ısınmanın yaratacağı, sosyo-ekonomik durgunluk, kriz ve göç hareketlerinin siyasi sonuçlarının önemsenmesine vurgu yapılmaktadır. Çalışmada, küresel ısınmaya ilişkin literatür taraması yapılmakta, dünyadaki belli bölgelerdeki 1sı anormalliğini gösteren değerler grafik, tablo ve haritalar ile gösterilmektedir. Çalı̧̧manın sınırlılıkları kapsamında, bazı bölgeler inceleme kapsamından çıkarılmaktadır. Isı anormalliği göstergelerinde yakın dönem olarak 2005-2020 yılları temel alınmaktadır. Çalışmanın sonucunda, 1sı anormalliğinin devam ettiği ve bunun da çevre faktörlerini bozarak yakın gelecekte uluslararası bir güvenlik problemi yarattığı görülmektedir. Bu durumda, dünyayı ve insanoğlunu tehdit eden küresel 1sınma problemi karşısında, ülkelerin bulundukları konumun jeopolitik açıdan önemsenmesi yerine dünyanın uzaydaki konumunun jeopolitik açıdan önemsenmesi gerekmektedir.

Anahtar kelimeler: Küresel 1sınma, iklim değişimi, çevre sorunu, çölleşme, 1s1 anormalliği, jeopolitik, uluslararası güvenlik

\begin{abstract}
In this study, it is emphasized that all the negative factors linked to global warming are threatening human security at the international level. Global warming poses a security problem which is dealt with in the environmental context of people, countries and therefore nation states. However, this apparently seeming as "innocent threat" in the context of the environment concept can also be the trigger for the background of regional and international crises. In this context, this study highlights the importance of the political consequences of socio-economic stagnation, crises and migratory movements caused by global warming. In the study, a review of the literature relating to global warming is carried out and the values projecting the temperature anomaly in certain regions of the world are shown with graphs, tables and maps. Certain regions are excluded from the scope of the study of this work. In the thermal anomaly indicators, the years of 2005-2020 are taken as the basis. As a result of the study, it is observed that the temperature anomaly continues, and this creates an international security problem in the near future by disrupting environmental factors. In this case, faced with the problem of global warming threatening the world and human beings, the importance of the geopolitics of the Earth in space must be considered instead of the geopolitics of countries where they are located in the world.
\end{abstract}

Keywords: Global warming, climate change, environmental problem, desertification, temperature anomaly, geopolitics, international security

\footnotetext{
${ }^{1}$ Doç.Dr., Anadolu Üniversitesi, İletişim Bilimleri Fakültesi, Basın ve Yayın Bölümü, Eskişehir, baertekin@anadolu.edu.tr, Orcid:0000-0002-7578-0879
} 


\section{GíRIŞ}

Her geçen gün artan nüfus, dünyanın mevcut sosyo-ekonomik ve doğal kaynaklarına ve zenginliklerine eşit bir şekilde ortak olmaktadır. 1961'de nüfus büyüme oranı 1.354 iken bu oran 2018 'de 1.105 oranına (Population growth (annual \%) | Data, 2020) düşmüş olmasına rağmen, dünya nüfusu 2018'de binde 7.529 ölüm oranına (Death rate, crude (per 1,000 people) | Data, 2020) karșın 18.175 (Birth rate, crude (per 1,000 people)| Data, 2020) doğum oranı ile 2019 y1lında 7 milyar 673 milyon 534 bin (Population 2019, 2020: 4) nüfusa ulaşmıştır. Bu rakam her geçen gün artarak büyümektedir. 15.yüzyılda 450 milyon olan dünya nüfusu, 1900'de 1,5 milyar iken 2050'de 10 milyar olması tahmin edilmektedir (Ramonet, 2005 :6). Makro düzeyde bir değerlendirmeye göre nüfusu her geçen gün artan ve kaynakları ve üretimi o nüfus oranına göre pay edilen böyle bir dünyada eğer İsviçre'nin yaşam düzeyi ve yaşam kalitesi baz alındığında dünya gezegenin, 600 milyon kişinin ihtiyaçlarını temin edebileceği ve eğer Bangladeşli çiftçilerinin tutumluluklarına göre bir yaşam düzeyi kabul edildiğinde ise, bu rakamın 18 ile 20 milyar nüfusun ihtiyaçlarına cevap verebilecek düzeyde olacağı öngörülmektedir (Ramonet, 2005:6). Bir ironi barındıran bu karşılaştırmada, verilen mesaj çok açıktır. Dünya nüfusu arttıkça, dünya kaynaklarından pay alanların sayısı ve yaşam kalitesi azalacaktır. Dünya nüfusu ve dünya kaynakları arasında kurulmuş olan bu korelasyon, aynı zamanda dünya nüfusunun artması ile eğer gerekli önlemler alınmaz ise insani yaşam kalitesinin de nüfusun büyüme oranına göre düsşeceğini göstermektedir. $\mathrm{Bu}$ bağlamda, dünya mevcut kaynaklarının korunması önem arz ederken küresel 1sınma ve küresel çölleşme problemleri, dünya nüfusu yaşam kalitesinin arttırılması çabalarına doğal engel olmaktadır. Küresel çölleşme aynı zamanda dünya tarım alanlarının çölleşmesi ve gelecekte stratejik açıdan küresel gıda sorununun dünya nüfusunu etkileyeceği anlamına gelmektedir.

\section{YÖNTEM}

Küresel 1sınmanın küresel bir tehdit olması ve bu tehdidin uluslararası güvenlik açısından yaratmakta olduğu ve yaratacağı olumsuzluklara dikkat çekmek için hazırlanmış olan bu çalışmada, konu ile ilgili literatür araştırması yapılmış, küresel ısınmanın 1sı anormalliğini ortaya koyan ölçüm değerlerine yer verilmiştir. Çalışmada, günümüzde artarak devam eden ve yakın gelecekte ise çok daha vahim sonuçları beraberinde taşıyan küresel çölleşme ve diğer çevre problemlerinin nedeni olan küresel 1sınma ve 1s1 anormalliği üzerinde durulmuştur. Araştırma kapsamında, detaylı bir literatür taraması yapılarak, gerekli veriler incelenmiş ve bu verilerden elde edilen grafik ve tablolara çalışmada yer verilmiştir. Çalışma ayrıca harita resimleri ile de desteklenmiştir. Çalışmanın sınırlılığı kapsamında, dünya genelindeki kara ve okyanus 1sı anormalliği verilerinin zaman serisi için değişik yıllar örneklenirken, özellikle Afrika, Asya, Avrupa, Kuzey Amerika ve Güney Amerika kitaları 1sı anormalliği NOAA verileri içinden sadece 2005-2020 yılları (mayıs ayı) kullanılmıştır. Sayfa sınırlaması dikkate alınarak, 1880 yılından itibaren aylık veya yıllık kümülatif toplam verilerin kullanılması yerine, mayıs ayı değerlerinin kullanılması tercih edilmiştir. Çalışmada mayıs ayının dışında farklı zaman serilerinin kullanılmaması araştırmada bir eksiklik yaratmamaktadır.

$\mathrm{Bu}$ çalışmanın birinci aşamasında, küresel 1sınma sorunu, ikinci aşamasında Afrika bölgesi 1sı anormalliği, üçüncü aşamasında, Asya bölgesi 1sı anormalliği, dördüncü aşamasında Avrupa bölgesi 1S1 anormalliği, beşinci aşamasında, Kuzey Amerika bölgesi 1sı anormalliği ve altıncı aşamasında Güney Amerika bölgesi 1sı anormalliği veriler ile incelenmiştir.

\section{KÜRESEL ISINMA PROBLEMININ TANITILMASI}

Dünya küresel 1sınma problemi ile karşı karşıya bulunmaktadır. Küresel 1sınma buzul erimelerine ve deniz seviyelerinin yükselmesine neden olduğu gibi, mevsim dengelerinin bozulmasına, verimli yağışların yerine sel felaketlerine ve toprak kayıplarına neden olan tropikal kaynaklı yağmurların yağmasına, hava sıcaklıklarının artmasına ve çölleşmeye neden olmaktadır. Küresel 1sınma ayrıca havadaki karbon döngüsünü bozmaktadır (Rabourdin, 2007:33). Bu küresel 1sınma döngüsü tek taraflı ve kısır bir döngüden de ibaret değildir. Bütün bu olumsuz olaylara neden olan küresel ısınma ayrıca doğanın kendi başına ürettiği bir olay da değildir. Doğa dengesinin bozulması, 
özellikle dünyanın akciğeri olarak tabir edilen ormanların, doğal kaynakların kullanımı, sanayi, üretim tesislerinin faaliyeti, turizm ve yeni yerleşim birimlerinin açılması, yanlış ve bilinçsiz kentleşme kısaca modernleşme adına tahrip ve yok edilmesinin dışında, sanayileşme ve teknolojinin getirdiği olumsuzluklar ile fosil atık bazlı enerjilerin kullanılması, küresel boyuttaki kara, hava ve deniz taşıtlarının yaydığı karbondioksit ile oluşan sera gazının atmosferi etkilemesi şeklinde sıralanabilecek birçok faktöre bağlıdır.

$\mathrm{Bu}$ kırılganlık, bir anlamda uluslararası sistemin geçirmiş ve yaşamış olduğu sanayileşme devrimi ile alakalıdır. Son yüzyılda, dünya gezegeninin sıcaklığı santigrat derecenin dörtte üçü oranında artmıştır. Bu küresel sıcaklık artışı bir $4^{\circ} \mathrm{C}$ daha artma durumunda hem Grönland hem de Antarktika buzulları erime riski altında bulunmaktadır (Silver, 2008: 2). Bu küresel 1sınma problemlerine bağlı olarak dünya bir anlamda büyük bir ikilem yaşamaktadır. Bu ikilem, bir taraftan dünya üzerinde kurulu üretim, sanayileşme tesislerinin faaliyet zorunluluğu ve her an durmaksızın devam eden ulaşım sirkülasyonun sosyoekonomik ve siyasi nedenler ile devam etmesini gerekli kılarken, diğer taraftan dünyadaki verimli yaşam alanlarının hızlı bir şekilde azalmasıdır. Yakın ve orta gelecekte de dünyada tarım alanlarının azalmasıyla birlikte dünyada çok ciddi küresel bir gıda sorununun uluslararası boyutta yaşanma riski vardır.

2013 verilerine göre, dünyada 168 ülke çölleşmeden etkilenmekte olup bunlar içinde 110 ülke risk altında bulunmaktadır (King, 2013).

Dünyada temel algı olan "dünya bize yeter" algısı temelde günümüz nesli için belki doğru ancak gelecek nesiller dikkate alındığında yanlış bir algıdır. Olaya bu bağlamda eğilmenin gerekliliği önem arz etmektedir. Bu duyarlılık içinde, Birleşmiş Milletlere üye her üye ülkenin küresel seferberlik ile bu konuda verimli ve önleyici çabalar sarf etmesi ve uygulama içinde olması gerekmektedir. Yine aynı şekilde, yatırımları MAI gibi uluslararası antlaşmalar ile her zaman korunan ve tüzel kişilikleri güvence altına alınan dünyanın karşı karşıya kaldığı bu küresel ısınma probleminde sorumluluğu olan çokuluslu şirketlerin de BM üyesi ülkeler ile uyumlu çalışması gerekmektedir. Bu zorunluluk, devamlı artan küresel ısınmanın büyük bir tehdit oluşturmasından da kaynaklanmaktadır. Yüz yıl önce dünyada ortalama hava sıcaklığı $13,7^{\circ} \mathrm{C}$ iken bugün bu hava sicaklığ seyretmektedir (Silver, 2008:11).

İklimi değerleri sadece $2^{\circ} \mathrm{C}$ ssınan bir dünya hipotezinde, Hükûmetlerarası İklim Değişikliği Paneli (IPCC / GIEC) raporuna göre, dünyada bölgeler arasında 1s değişim etkileri yeniden yapılanacak ve bu değişimin sonuçları havada homojen olmayacaktır. Bununla beraber, İskandinav ülkelerinde 1sı yüksekliği tarım için olumlu etkileri olsa da dünya genelinde olumsuz etkileri devam edecektir (Martin, 2015:14-15). Oysa, sera gazı emisyonlarındaki henüz kontrol altına alınamayan mevcut duruma göre, yüzyılın sonunda 1 s1 anormalliği en az $4^{\circ} \mathrm{C}^{\prime}$ lik bir artışa yol açacaktır. IPCC'nin raporuna göre, 1S1 anormalliği sonucunda da etkileri deniz seviyesinin 7 metre artması ve kıyıların sular altında kalmasına neden olacak bir senaryonun gerçekleşmesi durumunda bin yıl içinde Grönland tamamen ortadan kalkacaktır. Bu kritik eşiğin $1^{\circ} \mathrm{C}-4^{\circ} \mathrm{C}$ arasında olduğu tahmin edilmektedir. Oysa, Paris İklim Antlaşması görüşmelerinde küresel boyutta 1s1 anormalliğinin $2^{\circ} \mathrm{C}$ düzeyinde tutulmasına yönelik çaba ve öneriler paylaşılmaktadır. Yakın gelecekte sular altında kalma tehdidi altında olan Pasifik ada devletleri ise bu düzeyin maksimum $1,5^{\circ} \mathrm{C}$ düzeyinde tutulmasını önermişlerdir (Martin, 2015:14-15).

Harita 1 ve Harita 2, 1880 ve 2020 yılları mayıs ayı baz alınarak küresel ölçekte 1s1 anormalliğini haritalandırmaktadır. 1880 yılında daha orta küresel boyutta bir tehlike yok iken 2020 haritasında, Kuzey Batı Amerika, Güney Amerika, tüm Afrika kıtası, Asya, Orta-Doğu, Kuzey ve Güney Küre'de bu 1sı anormalliği görülmektedir. 


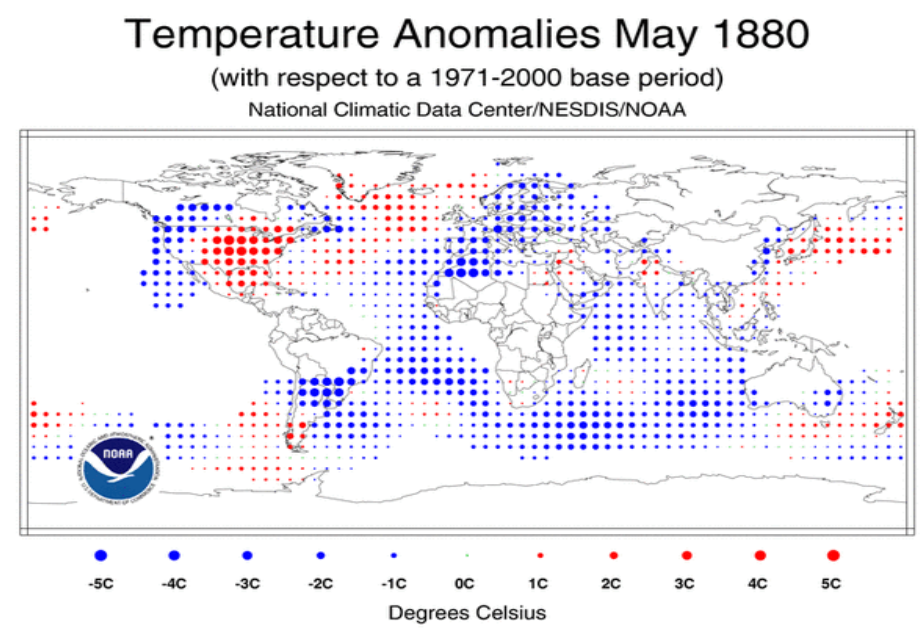

Kaynak: Global Temperature and Precipitation Maps | Temperature, Precipitation, and Drought | National Centers for Environmental Information (NCEI). (2020, July 8). NOAA, National Centers For Environmental Information. $\quad$ https://www.ncdc.noaa.gov/temp-and-precip/global-maps/188005?products[]=map-blendedmntp\#global-maps-select ; https://www.ncdc.noaa.gov/monitoring-content/sotc/global/map-blended-mntp/mapblended-mntp-188005.gif

Harita 1. 1880 Yı1ı Mayıs Ayı Ortalamasıyla Yerküre Kara ve Okyanus Isı Anormalliği

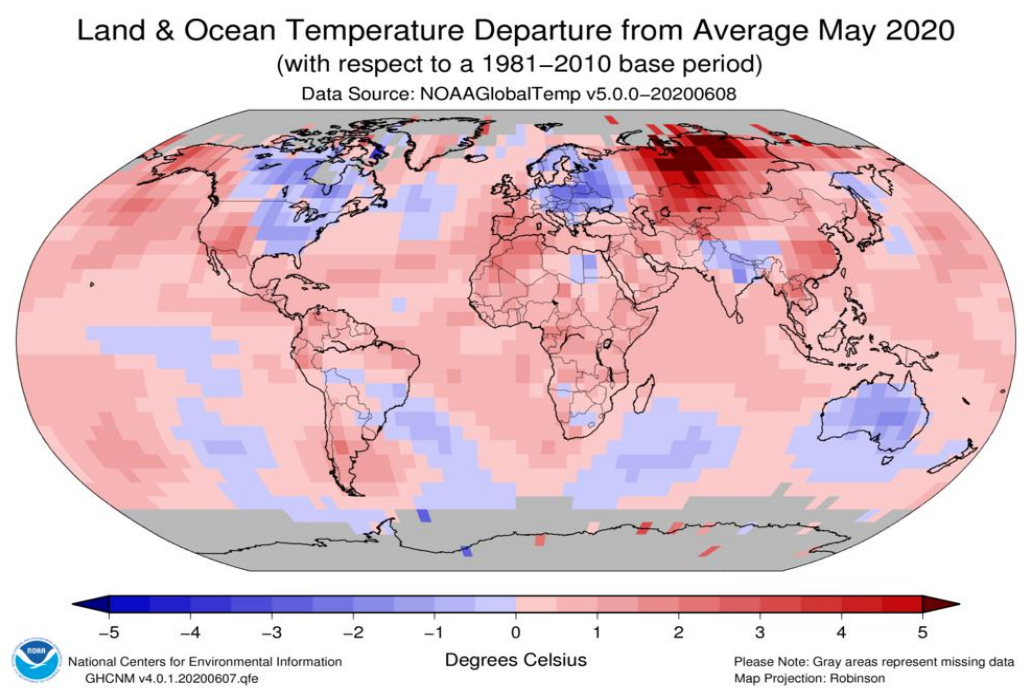

Kaynak: Global Temperature and Precipitation Maps | Temperature, Precipitation, and Drought | National Centers for Environmental Information (NCEI). (2020, July 8). NOAA, National Centers For Environmental Information. $\quad$ https://www.ncdc.noaa.gov/temp-and-precip/global-maps/202005?products[]=map-blendedmntp\#global-maps-select

Harita 2. 2020 Yılı Mayıs Ayı Ortalamasıyla Yerküre Kara ve Okyanus Isı Anormalliği

Harita 3'te (Helldén \& Tottrup, 2008:171) ise 1sı anormalliğinin küresel boyutta ve her farklı kıtanın belli bölgelerinde etkisini daha yoğun gösteren bir çölleşmenin meydana geldiği açıkça görünmektedir. 


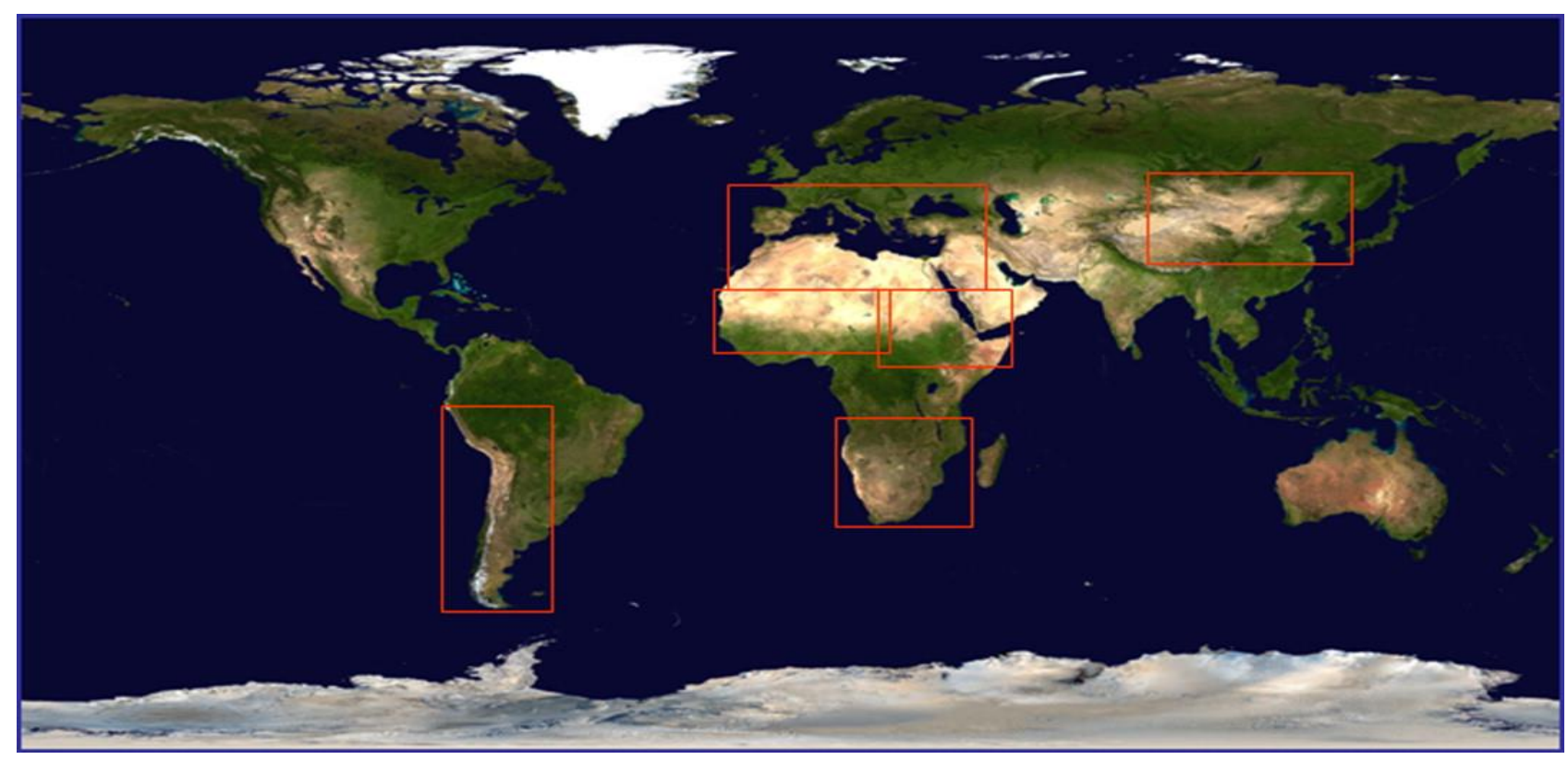

Kaynak: Helldén, U., \& Tottrup, C. (2008). Regional desertification: A global synthesis. Global and Planetary Change, 64(3-4), 171, (169-176). https://doi.org/10.1016/j.gloplacha.2008.10.006 ; https://ars.elscdn.com/content/image/1-s2.0-S0921818108001276-gr1.jpg

Harita 3. Küresel Isı Anormalliği Sonucunda Riskli Kıtasal Çölleşme Bölgeleri

Küresel 1S1 anormalliği hakkında bir makro düzeyde fikir veren bu haritaların incelenmesinden sonra, aşağıdaki verilerin incelenmesi küresel 1sı anormalliğini yıllara ve bölgelere göre değerlendirme açısından önemlidir.

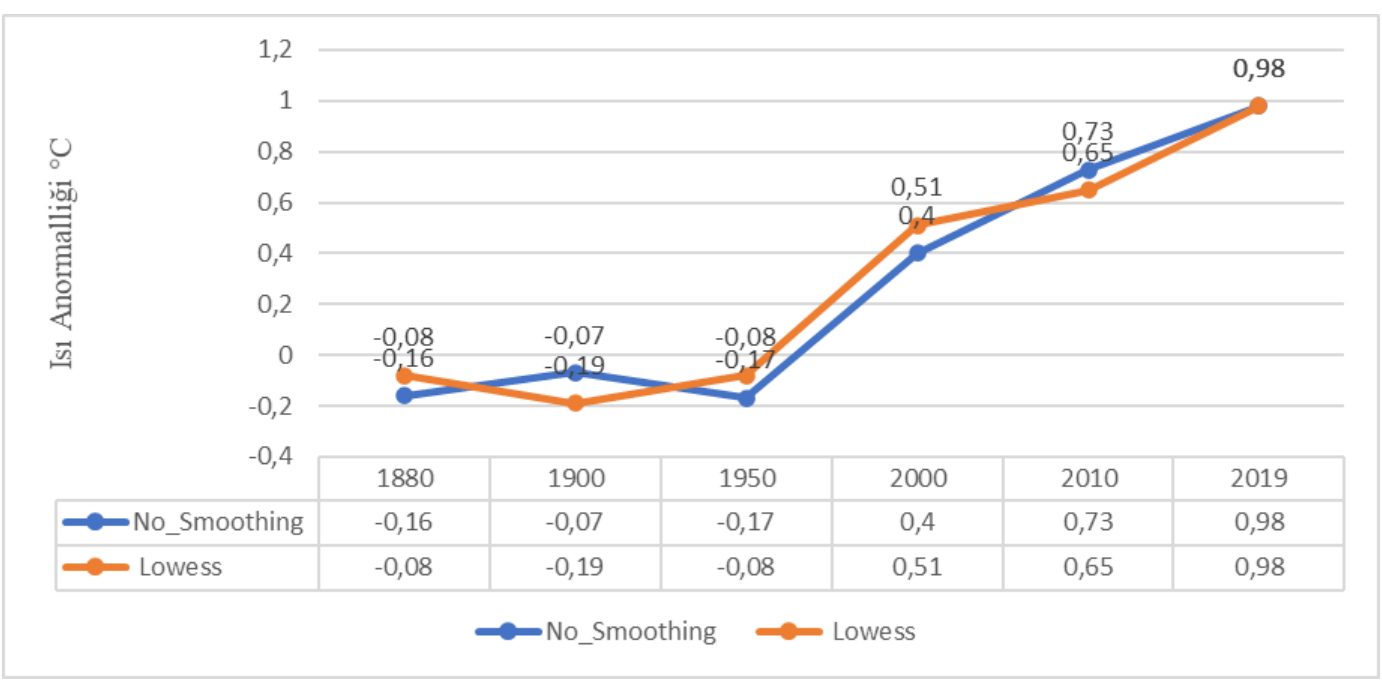

Kaynak: Grafik1 Global Temperature, NASA: Climate Change and Global Warmings. (2020, July 5). NASA. https://climate.nasa.gov/vital-signs/global-temperature/ 'den elde veriler ile çizilmiştir.

Grafik 1. 1880- 2019 Yılları Arasında Küresel Kara Parçası - Okyanus Sıcaklık Endeksi

Sıcaklık Grafik 1'de görüldüğü gibi, 1880 yılı ile karşılaştırıldığında, 2019 yılında 1s1 anormalliği $0,98^{\circ} \mathrm{C}^{\prime}$ a kadar artmış bulunmaktadır. 1880 , 1900 ve 1950 'li yıllarda görülen negatif anormallik yerini $1950^{\prime}$ li yıllardan sonra pozitif anormalliğe bırakmıştır. 1880 yılına göre $+1,06^{\circ} \mathrm{C}^{\prime}$ lık bir artış bulunmaktadır. 
Daha detaylı yakın dönem incelendiğinde dünyada 1S1 anormalliğinin arttığ 1 tespit edilmektedir. Grafik 2'de 2000-2020 yılları arasındaki yerkürede karalardaki 1sı anormalliği artış1 görülmektedir.

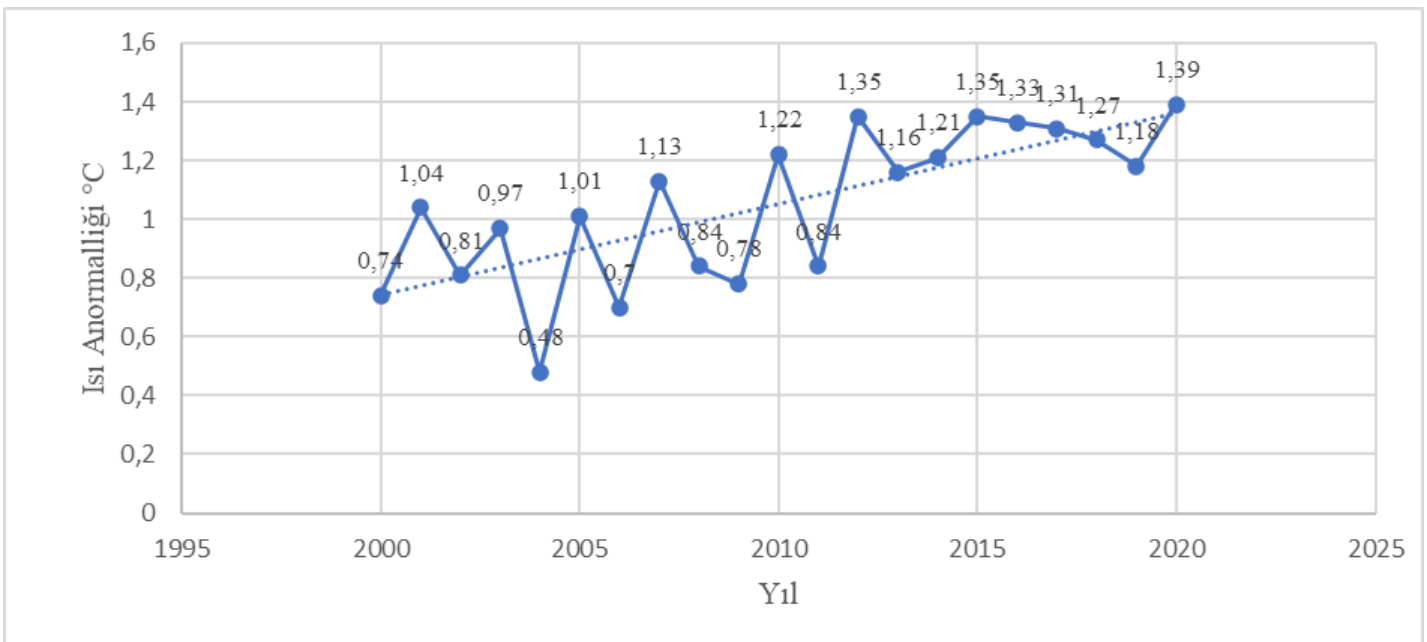

Kaynak: Grafik 2. Climate at a Glance | National Centers for Environmental Information (NCEI). (2020, July 6). NOAA. https://www.ncdc.noaa.gov/cag/global/time-series/globe/land/1/5/2000-

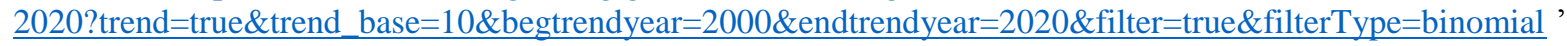
den elde edilen veriler ile çizilmiştir.

Grafik 2. 2000-2020 Yılları Arasında Yerküre -Kara Üzerinde Tespit Edilen Isı Anormalliği $\left({ }^{\circ} \mathrm{C}\right)$ (Mayis)

Doğal olarak aynı artış okyanuslarda da görülmektedir. Grafik 3 okyanuslardaki 1sı anormalliği artışını somut bir şekilde göstermektedir.

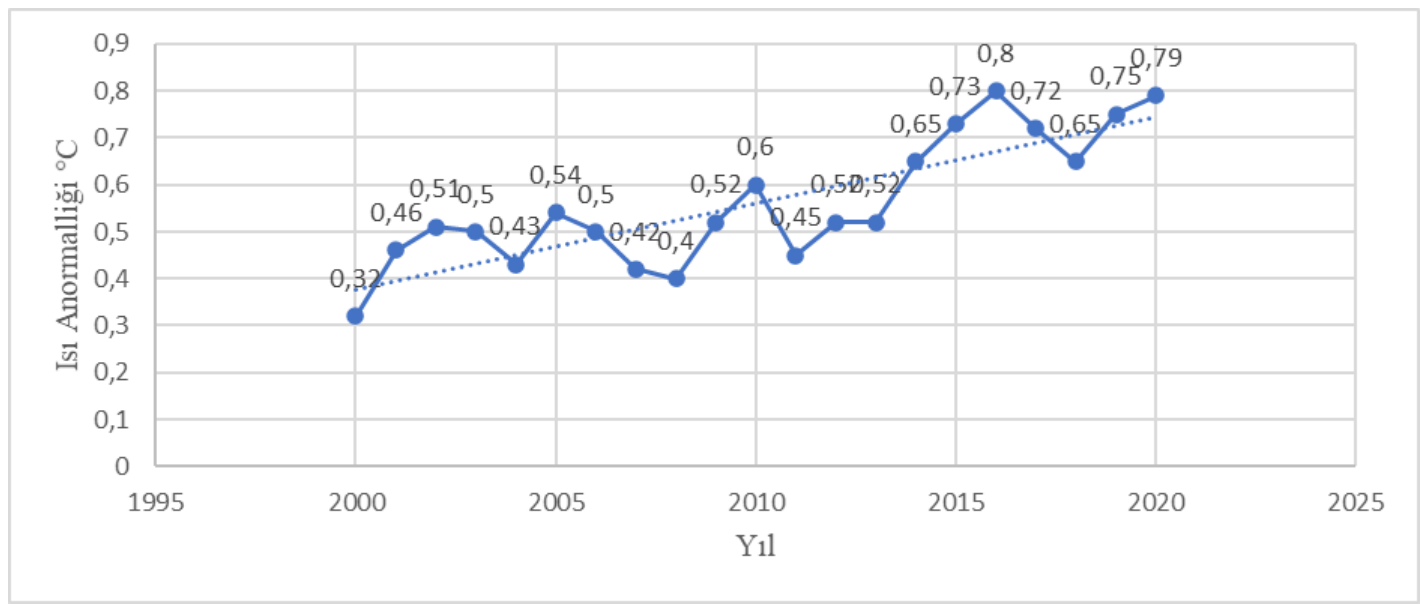

Kaynak: Grafik 3. Climate at a Glance| National Centers for Environmental Information (NCEI). (2020, July 6). NOAA. https://www.ncdc.noaa.gov/cag/global/time-series/globe/ocean/1/5/2000-

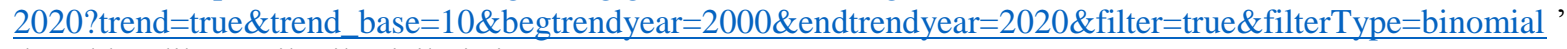
den elde edilen veriler ile çizilmiştir.

Grafik 3. 2000-2020 Yılları Arasında Okyanus Suyu Isı Anormalliği ( $\left.{ }^{\circ} \mathrm{C}\right)$ (Mayıs)

Küresel 1sınmadaki anormalliği daha iyi görmek için 1800'li yılların verilerini incelemek gerekmektedir. 1800'li yıllarda bugünkü verilerin aksine bir durum söz konusu bulunmaktadır. Bu durum 1930'lu yıllara kadar devam etmiştir. Şekil 1'de bugünkü 1s1 
artışının 1880-1930 yılları arasında bir anormalliğe dönüşmeden önceki verileri yer almaktadır. Şekil 1'de 1S1 eğilimlerinin henüz aşağıya doğru eğilim göstermesi bu yıllarda henüz 1Sı anormalliğinin bir artış göstermediği anlamına gelmektedir.

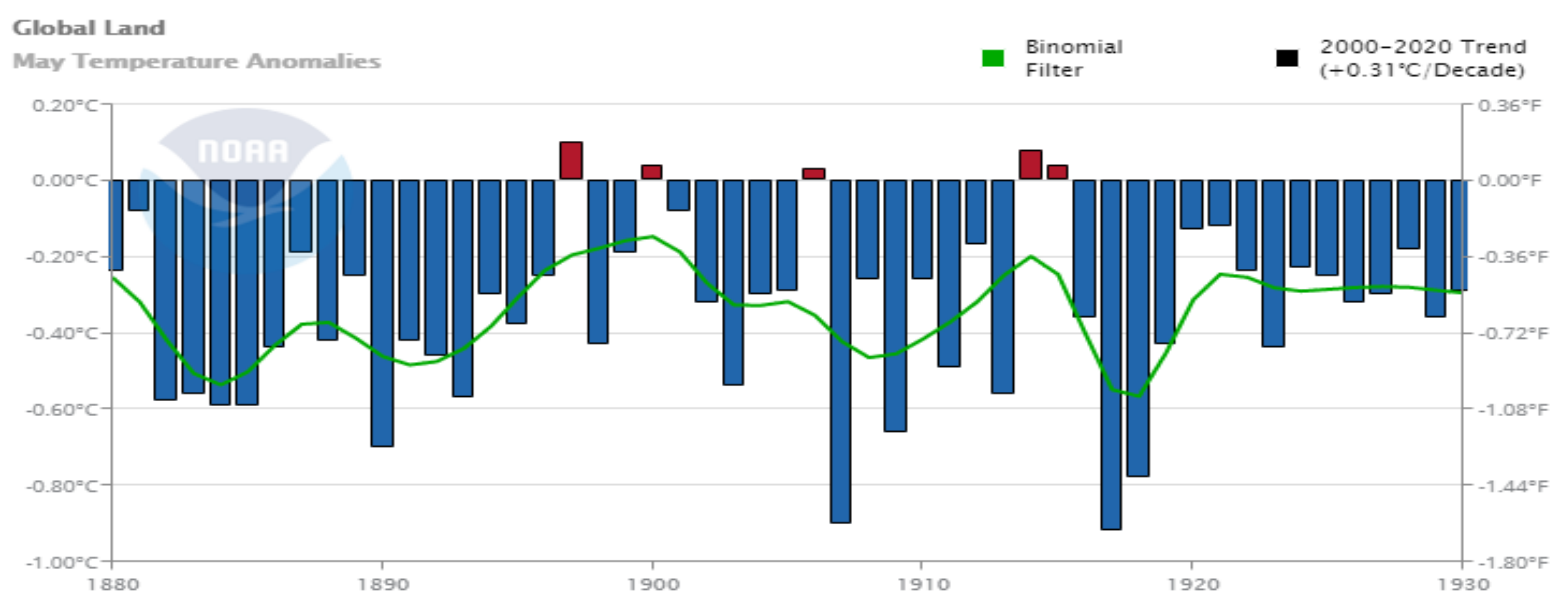

Kaynak: Climate at a Glance | National Centers for Environmental Information (NCEI). (2020, July 6). NOAA. https://www.ncdc.noaa.gov/cag/global/time-series/globe/ocean/1/5/1880https://www.ncdc.noaa.gov/cag/global/time-series/globe/land/1/5/1880-

1930 ?trend=true\&trend base $=10 \&$ begtrendyear $=2000 \&$ endtrendyear $=2020 \&$ filter $=$ true \&filterType $=$ binomial

Şekil 1. 1880-1930 Yılları Arasında Yerküre -Kara Üzerinde Tespit Edilen Isı Anormalliği $\left({ }^{\circ} \mathrm{C}\right)$ (Mayıs)

Şekil 1'deki verilere göre, 1880 yılında dünya kara parçası üzerinde $-0,24^{\circ} \mathrm{C}$ olan $1 \mathrm{~S} 1$ sıcaklığı anormalliğii, 1930 yılında $-0,29^{\circ} \mathrm{C}$ civarında negatif anormalliğini korumuştur.

Şekil 2'de ise, günümüzde tartışılan 1sı anormalliğinin henüz etkin olmadığı çubuk grafikler yardımı ile görülmektedir. 1880 yılında okyanus 1sı sıcaklığı anormalliği mayıs ayı ölçümlerinde $-0,05^{\circ} \mathrm{C}$ iken, 1930 yılında $-0,15^{\circ} \mathrm{C}$ civarında negatif olarak tespit edilmiştir. 


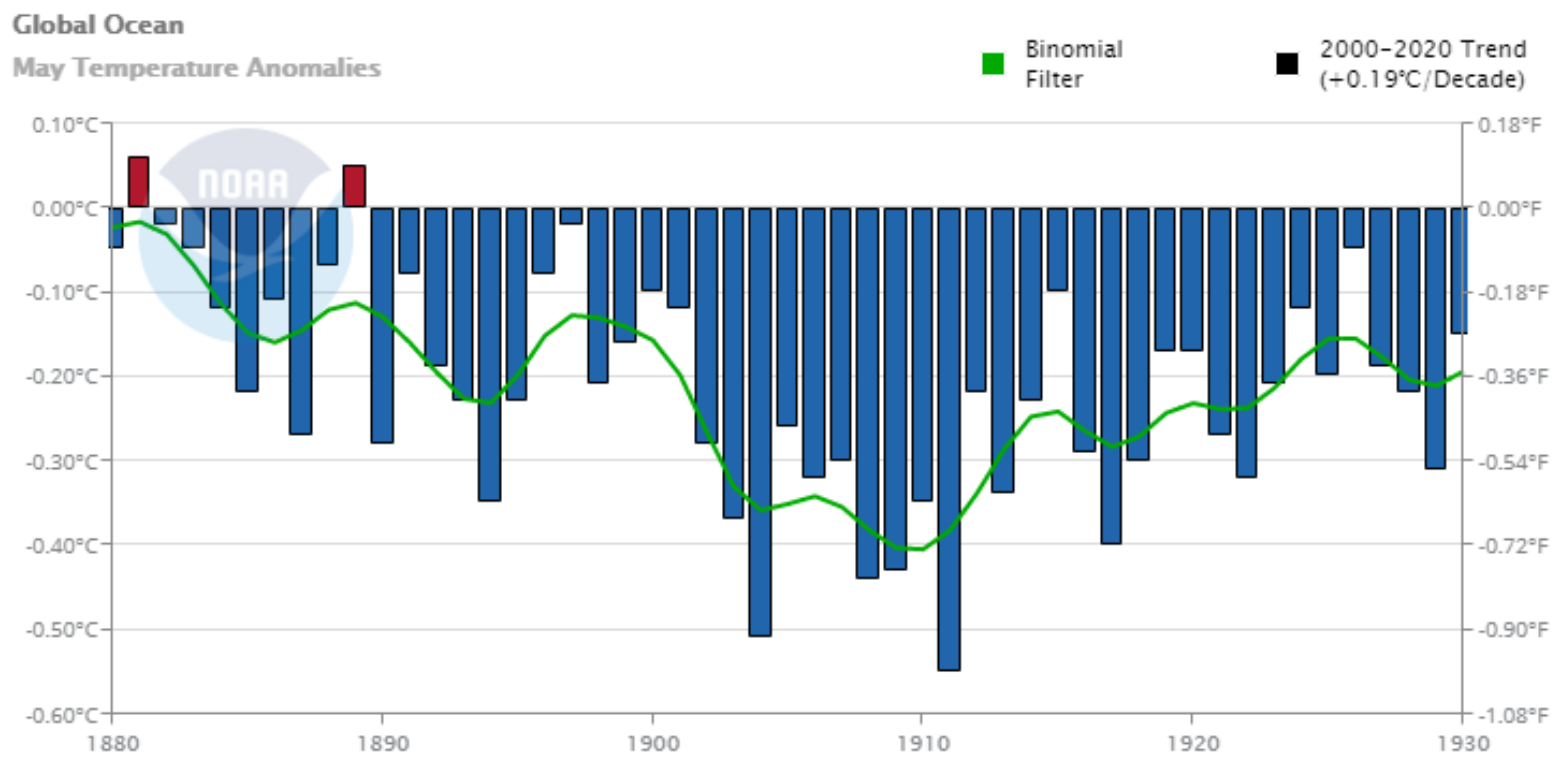

Kaynak: Climate at a Glance | National Centers for Environmental Information (NCEI). (2020, July 6). NOAA https://www.ncdc.noaa.gov/cag/global/time-series/globe/ocean/1/5/18801930 ?trend=true\&trend base $=10 \&$ begtrendyear $=2000 \&$ endtrendyear $=2020 \&$ filter=true \&filterType=binomial

Şekil 2. 1880-1930 Yılları Arasında Okyanus Su Isı Anormalliği $\left({ }^{\circ} \mathrm{C}\right)$ (Mayıs)

1931- 1975 yılları arasında ise yerküre kara sıcaklığı anormalliği $1931^{\prime}$ de $-0,36^{\circ} \mathrm{C}$ olan negatif 1 s1 anormalliği ve 1975 'te ise pozitif olarak $0,23^{\circ} \mathrm{C}$ seviyesindedir. $1931-1975$ yılları arasındaki okyanus suyu 1S1 anormalliği ise, $1931^{\prime}$ de negatif ölçümle $-0,07^{\circ} \mathrm{C}$ ve $1975^{\prime}$ 'te pozitif olarak $0,02^{\circ} \mathrm{C}^{\prime}$ dir. Şekil $2^{\prime}$ 'de hem yer küre kara parçası ve hem de okyanus is1 anormalliği 1976-2000'li yıllar arasındaki 1sı anormallikleri açık bir şekilde görülmektedir.

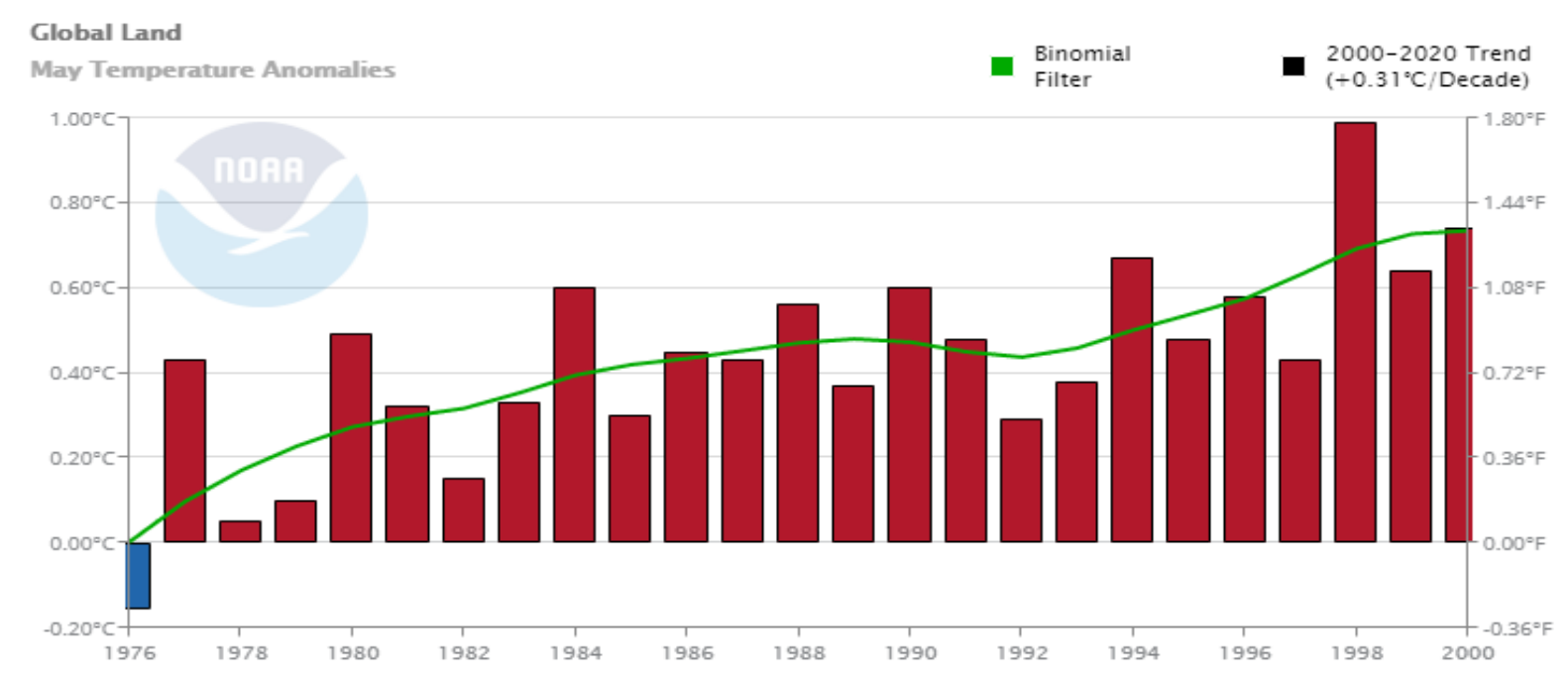

Kaynak: Climate at a Glance | National Centers for Environmental Information (NCEI). (2020, July 6). NOAA https://www.ncdc.noaa.gov/cag/global/time-series/globe/land/1/5/1976-

2000? trend=true\&trend base $=10 \&$ begtrendyear $=2000 \&$ endtrendyear $=2020 \&$ filter $=$ true \&filterType $=$ binomial

Şekil 3. 1976-2000 Yılları Arasında Yerküre -Kara Üzerinde Tespit Edilen Isı Anormalliği $\left({ }^{\circ} \mathrm{C}\right)$ (Mayis) 
Şekil 3'de yerküre kara parçası üzerinde 1976 y1lında $-0,16^{\circ} \mathrm{C}$ olan negatif 1 s1 anormalliği, 2000 yılında $0,74^{\circ} \mathrm{C}$ 'a ulaşmaktadır. Şekil $4^{\prime}$ teki okyanus suyu 1sı anormalliği ise 1976 ' da $-0,11^{\circ} \mathrm{C}$ civarında olan negatif 1 sı anormalliğinin 2000 yılında $0,32^{\circ} \mathrm{C}^{\prime}$ a ulaştı̆g 1 görülmektedir.

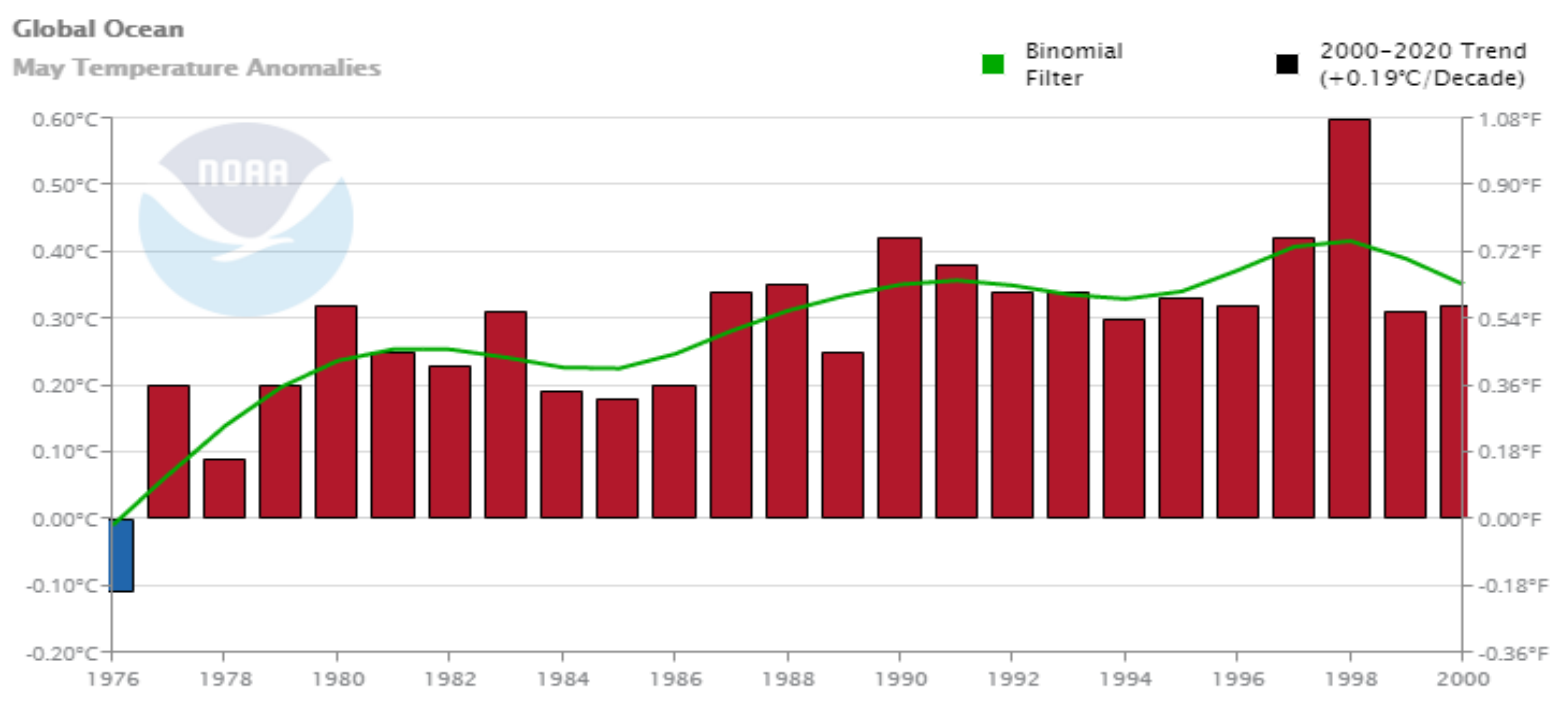

Kaynak: Climate at a Glance | National Centers for Environmental Information (NCEI). (2020, July 6). NOAA https://www.ncdc.noaa.gov/cag/global/time-series/globe/ocean/1/5/1976-

2000 ?trend=true \& trend base $=10 \&$ begtrendyear=2000\&endtrendyear $=2020 \&$ filter $=$ true $\&$ filterType=binomial

Şekil 4. 1976-2000 Yılları Arasında Okyanus Su Isı Anormalliği $\left({ }^{\circ} \mathrm{C}\right)$ (Mayıs)

Şekil 3 ve Şekil 4'te yer alan verilere göre, küresel tehdit olan 1sı anormalliği, 1976 yılından itibaren artan 1sı anormalliğiyle karşılaştırıldığında 2020 yılında karada 1,39 (Grafik 2) ve okyanusta ise $0,79^{\circ} \mathrm{C}$ (Grafik 3) olduğu görülmektedir. Küresel ortalama değerleri inceledikten sonra, 1sı anormalliğinin ve çölleşmelerin yaşandığı dünyanın diğer bölgelerinin de örnek ve değerlendirme açısından verilerinin karşılaştırması gerekmektedir. Günümüzde, küresel ısınmanın yarattığı çölleşme problemlerini en çok hisseden kıta Afrika kıtasıdır.

\section{AFRİKA BÖLGESİ ISI ANORMALLİĞİ SORUNU: SAHRA BÖLGESİNDE EKILLEBILIIR ALANLARIN ÇÖLLEŞMESİ}

Afrika kıtasına ilişkin 2005-2020 yılları arasındaki 1sı değerleri incelediğinde bazen belli y1llara göre iyileşmeden çok azalma görünse de 1s1 anormalliği değerlerinin arttığ görülmektedir. Afrika kıtası diğer dünya kıtaları içinde en çok açlık ve fakirliğin yaşandığı ve sosyo-ekonomik gelişmesini adil ve eşit bir şekilde geliştirememiş, toplam kişi başına düşen GSYH'ın düşük olduğu bir coğrafi bölgedir. Bu açıdan ele alındığında, bir de bu bölgenin küresel 1sınmaya bağlı olarak çölleşmesi, üzerinde yaşayan kıta nüfusu için üzerinde önemli durulmasi gereken acil bir konudur.

Çölleşmenin sürmesi ekilebilir tarım arazilerinin bozulmasına neden olmaktadır. Çölleşmenin büyük bedeli olarak dakikada 23 hektar tarım arazisi bozulmaktadır (Bafana, 2017). Bu kısır döngü içinde bozulmuş topraklar Afrika'nın çoğunda önemli bir geçim kaynağı ve gıda kaynağı olan tarımı etkilemekte ve birçok insanın aç kalmasına yol açmaktadır. Dünyada 2,6 milyardan fazla insan ise tarımdan elde ettikleri ürün ve gelir ile yaşamaktadır. Birleşmiş Milletler Çölleşme ile Mücadele Sözleşmesi'ne (UNCCD) göre, 
ekilebilir tarım arazilerinin yarısından fazlası toprak bozulmasından etkilenmektedir (Bafana, 2017).

Sahra ve Sahel Bölgesi için Büyük Yeşil Duvar Girişimi (L'initiative Grande Muraille Verte pour le Sahara et le Sahel / IGMVSS)'un yayınladığı rapora göre çölleşme, iklim değişikliği ve biyolojik çeşitliliğin kaybı, Afrika'nın bu kurak bölgeleri için önemli sorunların başında gelmektedir. Bu olumsuz etkiler belli bir kalkınma çabası içinde olup aynı zamanda dünyanın en yoksul geçim kaynaklarına sahip olan bu ülke nüfuslarının içinde yaşadıkları bölgelerdeki gıda kırılganlığı sorununu ağırlaştırmaktadır (Stratégie Régionale harmonisée de mise en oeuvre de l'initiative " Grande muraille verte pour le Sahara et le Sahel », n.d. :6). $\mathrm{Bu}$ amaç doğrultusunda, Afrika, Karayipler ve Pasifik Grubu Ülkeleri ( African, Caribbean and Pacific Group of States / ACP) inisiyatifi olan Çölleşmeye Karşı Eylem (Action Against Desertification) grubu 1s1 anormalliğinden kaynaklanan çölleşme sorununa karşı Afrika'nın 6 ülkesi Burkina Faso, Etiyopya, Gambia, Nijer, Nijerya ve Senegal'e kurak ormanların ve meraların sürdürülebilir yönetim ve restorasyon konularında yardım etmektedir (Africa|Action Against Desertification | Food and Agriculture Organization of the United Nations, 2020). ${ }^{2}$ Grafik 4 ve Tablo 1'de görüldüğü gibi gıda, beslenme ve kalkınma sorunlarını iç içe yaşayan Afrika'nın özellikle bu bölgelerinde yaşanan 1sı anormalliği, doğaya karşı belli ölçülerde mücadele kapsamında kısmen yapılan insani çabaların istenilen seviyeye ulaşmasını engellemektedir.

Grafik 4 ve Tablo 1 'de bu 1sı değerlerine ilişkin verilerde 1sı anormalliği değerlerinin belli yıllarda daha düşük olduğu ancak en düşük $0,56^{\circ} \mathrm{C}$ değerinde, çoğunlukla da $0,56^{\circ} \mathrm{C}$ üzerinde veya $1{ }^{\circ} \mathrm{C}$ ve üzerinde seyrettiği görülmektedir.

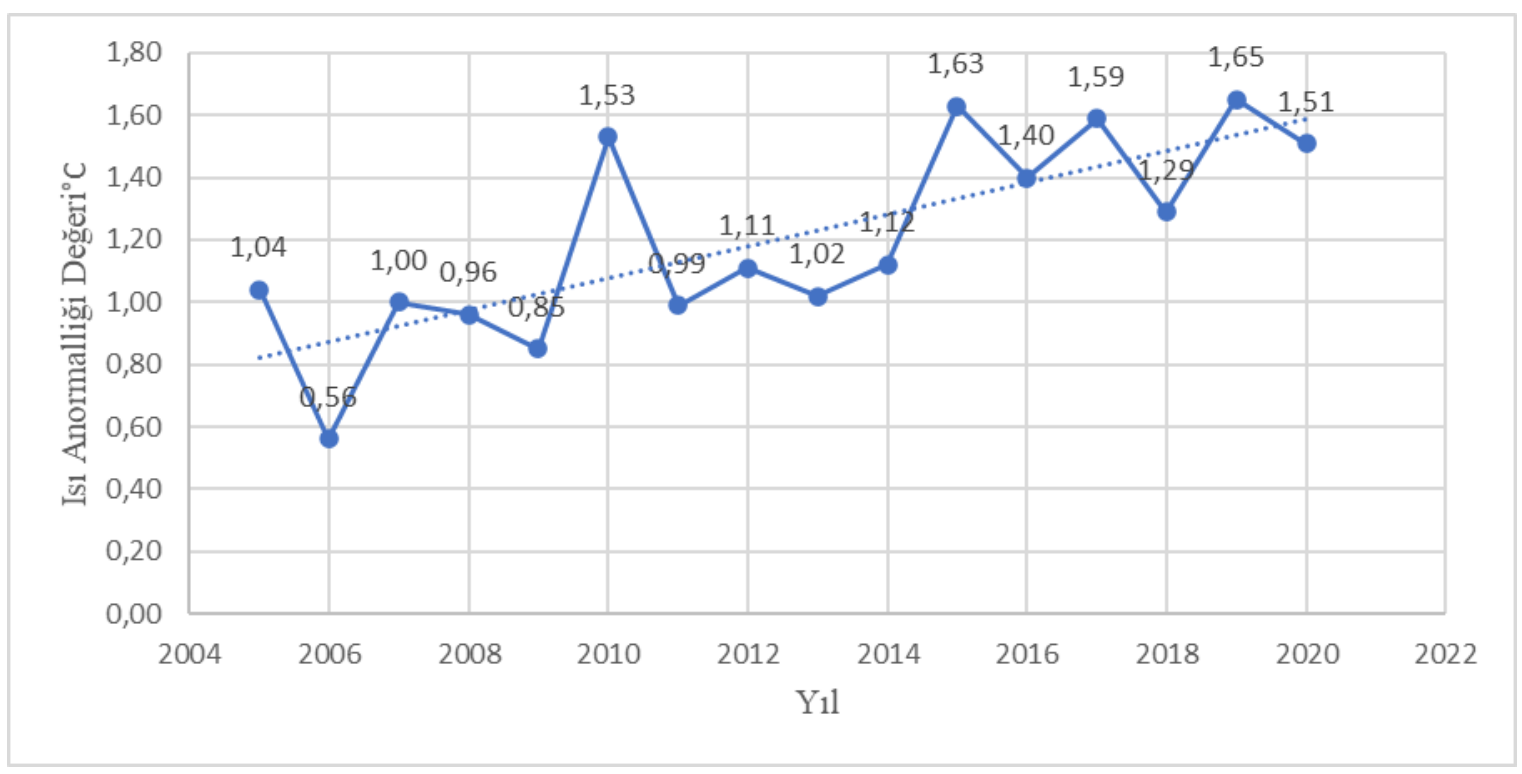

Grafik 4. 2005-2020 Yılları Arasında Afrika Kıtası Isı Anormalliği ( $\left.{ }^{\circ} \mathrm{C}\right)$ (Mayıs)

Kaynak: Climate at a Glance | National Centers for Environmental Information (NCEI). (2020, July 7). NOAA https://www.ncdc.noaa.gov/cag/global/time-series/africa/land/1/5/2005-

2020?trend=true\&trend base $=10 \&$ begtrendyear $=2000 \&$ endtrendyear=2020\&filter $=$ true \&filterType=binomial 'den elde edilen veriler ile çizilmiştir.

\footnotetext{
${ }^{2}$ Çölleşmeye Karşı Eylem (Action Against Desertification) grubunun öncelikli ülkeleri arasında Karayipler'de Haiti ve Pasifik'te de Fiji ülkesi bulunmaktadır. Bkz. Africa $\mid$ Action Against Desertification $\mid$ Food and Agriculture Organization of the United Nations. (2020). FAO. http://www.fao.org/in-action/action-againstdesertification/countries/africa/en/
} 
Tablo 1. 2005-2020 Yılları Arasında Afrika Kıtası Isı Anormalliği $\left({ }^{\circ} \mathrm{C}\right)$ (Mayıs)

\begin{tabular}{|c|c|}
\hline Yil & Değer \\
\hline 2005 & 1,04 \\
\hline 2006 & 0,56 \\
\hline 2007 & 1,00 \\
\hline 2008 & 0,96 \\
\hline 2009 & 0,85 \\
\hline 2010 & 1,53 \\
\hline 2011 & 0,99 \\
\hline 2012 & 1,11 \\
\hline 2013 & 1,02 \\
\hline 2014 & 1,12 \\
\hline 2015 & 1,63 \\
\hline 2016 & 1,40 \\
\hline 2017 & 1,59 \\
\hline 2018 & 1,29 \\
\hline 2019 & 1,65 \\
\hline 2020 & 1,51 \\
\hline
\end{tabular}

Kaynak: Climate at a Glance | National Centers for Environmental Information (NCEI). (2020, July 7). NOAA https://www.ncdc.noaa.gov/cag/global/time-series/africa/land/1/5/2005-

2020 ?trend=true \&trend base $=10 \&$ begtrendyear $=2000 \&$ endtrendyear $=2020 \&$ filter $=$ true $\&$ filter $T y p e=$ binomial 'den elde edilen veriler ile çizilmiştir.

Isı anormalliğinin yaratacağı felaket $+2^{\circ} \mathrm{C}$ etkiler göz önüne alındığında, bu felaketin getireceği gida güvenliği problemi küresel boyutta ve özellikle de Afrika'da önem arz edecektir (Martin, 2015:14-15). Yapılan bir çalışmaya göre (Burke et al., 2009) Afrika'da tarım alanlarının çölleşmesi farklı çatışmaları da beraberinde getirecektir. Senaryolar arasında, 1S1 artışı ve yağmurların azalmasından kaynaklanan Afrika Aşağı Sahra'sında verimli alanların kontrolü için silahlı çatışmaların 2030 yılına kadar \%54 artış göstereceği analizi dahi yapılmaktadır (Burke et al., 2009'den aktaran Sinaï, 2015:2). İster senaryo olsun isterse reel durumun analizi olsun, gözle görünen ve yaşanan hakikat Aşağ1 Sahra'da küresel isınmaya bağlı çölleşme fenomeninin kendisini ağır bir şekilde hissettirmesidir.

Oysa normal hayatta, “...zengin bir Kuzey Amerikalının fakir bir Afrikalıdan bin kat daha fazla sera gazı yaymasina... ”(Satterthwaite, 2009'den aktaran Bonneuil, 2015:16-17) ve Afrika kıtasının küresel 1sınmadaki payının en az payı olmasına rağmen, küresel boyutta çöllenmeden en çok zarar gören bölgeler arasında gelmektedir. Afrika bir bakıma bedeli sadece 1s1 anormalliği değil, 1s1 anormalliğinin getireceği diğer sorunlara da hazır olmak zorunda olan bir kıtadır (Rabourdin, 2007:33). Dolayısıyla Afrika ülkeleri bir yandan kalkınmaya çalışırken diğer yandan da çölleşme ve 1s1 anormalliği problemlerine karş1 uluslararası mercilerin de katkısıyla önlem almak zorundadır.

\footnotetext{
${ }^{3}$ Ayrıca Satterthwaite'ın ilgili çalışması için bkz. Satterthwaite, D. (2009). The implications of population growth and urbanization for climate change. 1-25,

https://www.uncclearn.org/sites/default/files/inventory/unfpa13.pdf , s.17
} 


\section{ASYA BÖLGESİ ISI ANORMALLİĞİ SORUNU: BANGLADEŞ'TE İKLİM GÖÇÜ VE ÇİN'DE HAVA KİRLİLİĞİ}

Grafik 5 ve Tablo 2'de görüldügü gibi, 2005 yılında +1,05 olan 1s1 anormalliği 2002 yılı mayıs ayında $+2,09$ 'a ulaşmıştır.

Is1 anormalliğinin Asya kıtasına etkisi bir bölgeden diğer bölgeye göre kademeli olarak değişiklik göstermektedir. Örneğin, Bangladeş \%0,3 veya \%0,4 sera gazı salgılama oranı 160 milyondan fazla nüfusu ile New York'tan bile daha azdır. Bununla beraber, küresel ısınmanın olumsuz etkilerini de bu bölge insanları yaşamaktadır. Bu nedenle, Bangladeş günümüzde iklim sorununa bağlı göçlerin yaşandığı ülkelerden biridir. Bu konuda, ülkelerin ortak sorumluluk kapsamında, bu türden yaşanacak felaketlerde iklim göçmenlerine topraklarını açmaları bile önerilmektedir (Garnier, 2007: 16-17).

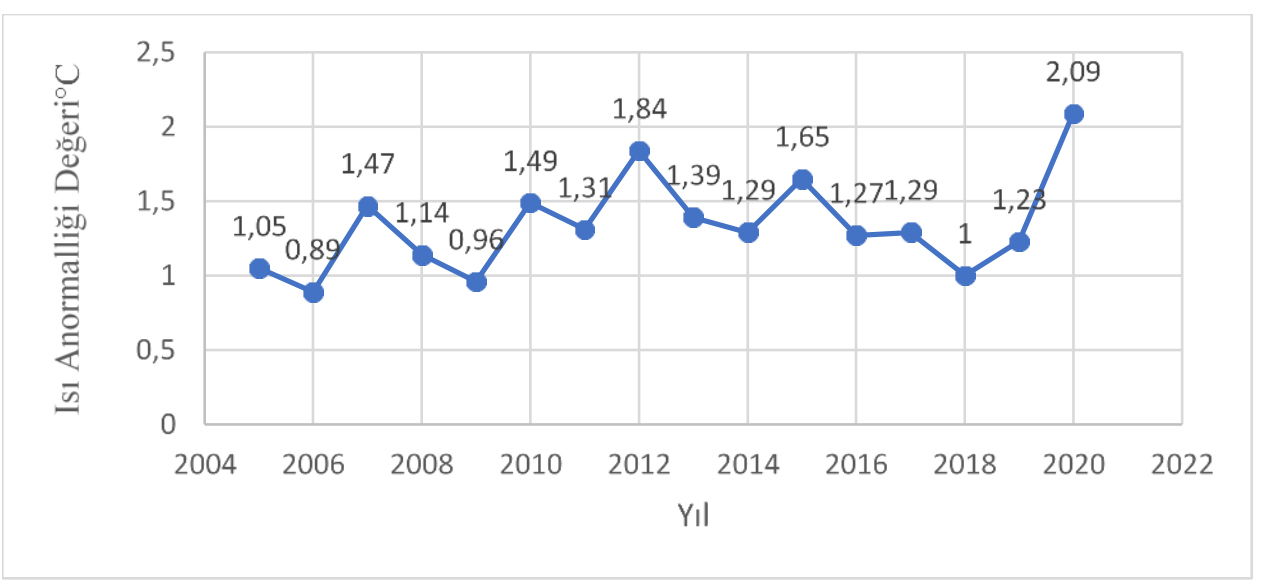

Kaynak: Climate at a Glance | National Centers for Environmental Information (NCEI). (2020, July 8). NOAA https://www.ncdc.noaa.gov/cag/global/time-series/asia/land/1/5/2005-

2020 ?trend=true \&trend base $=10 \&$ begtrendyear $=2000 \&$ endtrendyear $=2020 \&$ filter $=$ true $\&$ filterType $=$ binomial 'den elde edilen veriler ile çizilmiştir.

Grafik 5. 2005-2020 Yılları Arasında Asya Kıtası Isı Anormalliği $\left({ }^{\circ} \mathrm{C}\right)$ (Mayıs)

Asya'da kendisini etkin şekilde hissettiren, 1S1 anormalliğini (Tablo 2) tetikleyen bir büyük faktör de küresel buzul erimelerinin dışında hava kirliliğinin kıta üzerinde yarattığı olumsuz oluşumdur. Bu olumsuz faktörde en çok payı olan diğer bir kıta ülkesi de Çin'dir. Çin'de hava kirliliğine karşı büyük tepkiler olmasına rağmen bu tepkiler Çin hükümeti tarafından bastırılmaktadır. Hava kirliliği ve çevre eylemleri dağıtılmakta ve eylemcilerin liderleri tutuklanmaktadır. Bu konuda bazıları 30 ile 50 bin eylemden bahsederken barışçıl veya şiddet içeren yerel eylemlerin 2013'de 712 civarında olduğu otoriteler tarafindan belirtilmektedir (Pitron, 2017:6). Çin hükümetinin, hükümeti eleştiren çevre eylemlerine karş1 katı olmasına rağmen, Çin halkı çevre problemleri karşısında duyarlıdır ve sosyal medya üzerinden de organize olarak bu konuda katılım sağlamaktadırlar. Çin'de 2017 y1lı verilerine göre 731 milyon internet kullanıcısı ve 7 ile 8 milyar arasında Weibo sosyal medya hesabı bulunmaktadır (Pitron, 2017:7). Çevre eylemcileri ve Çin hükümeti arasındaki bu çelişkiye rağmen, Çin, ABD'nin Paris antlaşmasından çekilmesinden sonra küresel iklim değişikliği ve küresel 1sınma ya karşı eylemde liderliğe soyunması örnek gösterilmektedir. 
Pitron'un analizine göre;

“...Amerika'nın Paris anlaşmasından çekilmesinden sonra Pekin, küresel ısınmaya karşı mücadelede kendisini bir şampiyon olarak takdim etmektedir. Gezegendeki en kirli ülkede, merkezi otoriteler, kendileri sorgulanmamaları şartıyla, çevrecilerin girişimlerini memnuniyetle karşılamaktadırlar..." (Pitron, 2017:1).

Tablo 2. 2005-2020 Yılları Arasında Asya Kıtası Isı Anormalliği $\left({ }^{\circ} \mathrm{C}\right)$ (Mayıs)

\begin{tabular}{|c|c|}
\hline Yll & Değer \\
\hline 2005 & 1,05 \\
\hline 2006 & 0,89 \\
\hline 2007 & 1,47 \\
\hline 2008 & 1,14 \\
\hline 2009 & 0,96 \\
\hline 2010 & 1,49 \\
\hline 2011 & 1,31 \\
\hline 2012 & 1,84 \\
\hline 2013 & 1,39 \\
\hline 2014 & 1,29 \\
\hline 2015 & 1,65 \\
\hline 2016 & 1,27 \\
\hline 2017 & 1,29 \\
\hline 2018 & 1 \\
\hline 2019 & 1,23 \\
\hline 2020 & 2,09 \\
\hline
\end{tabular}

Kaynak: Climate at a Glance | National Centers for Environmental Information (NCEI). (2020, July 8). NOAA https://www.ncdc.noaa.gov/cag/global/time-series/asia/land/1/5/2005-

2020?trend=true\&trend base $=10 \&$ begtrendyear $=2000 \&$ endtrendyear $=2020 \&$ filter $=$ true \&filterType $=$ binomial 'den elde edilen veriler ile çizilmiştir.

Harita 4'de (Marin, 2017:6) Çin'in hava kirliği oranlarının en çok olduğu bölgeler görülmektedir. 


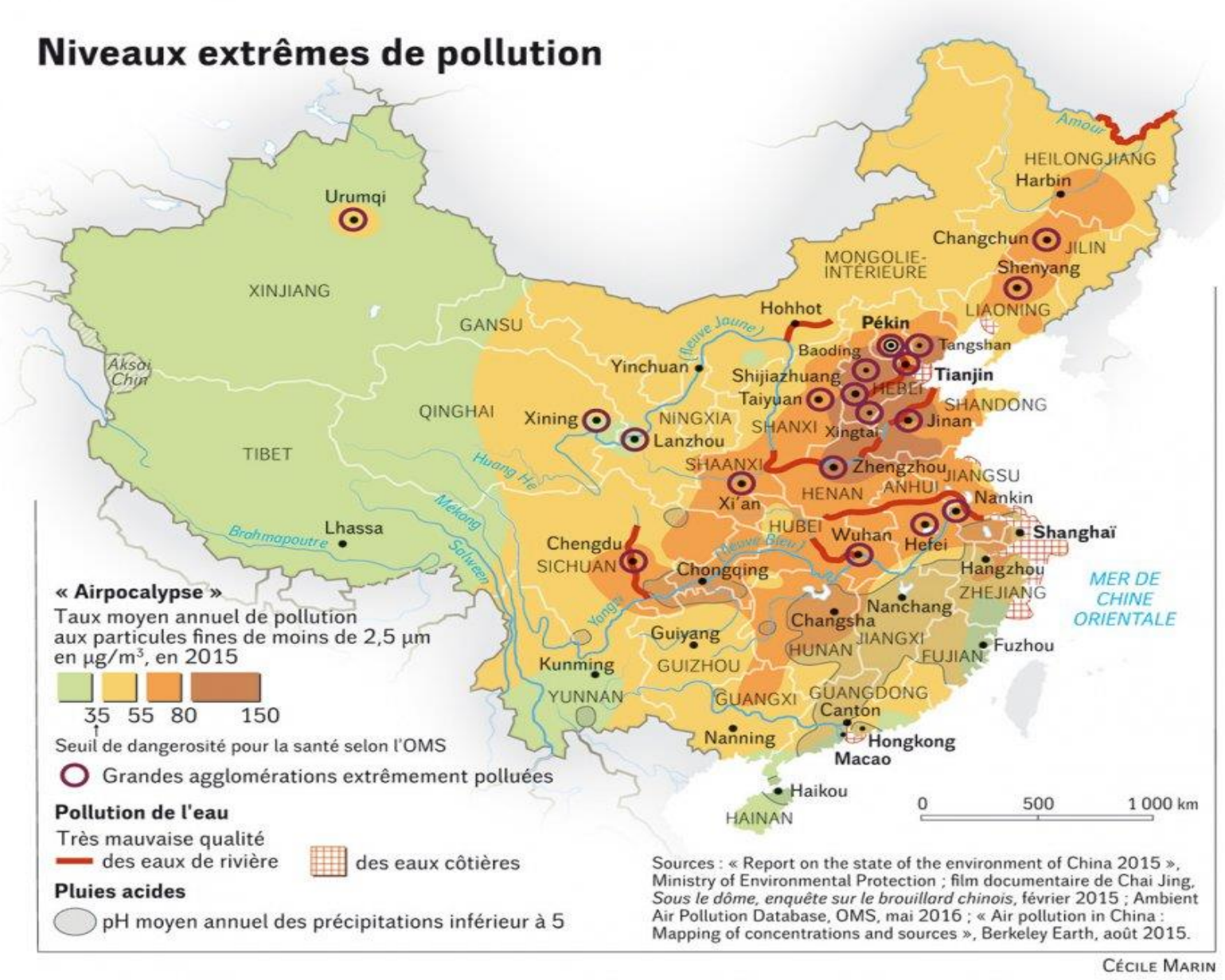

Kaynak: Marin, C. (2017, July). Niveaux extrêmes de pollution en Chine. Le Monde Diplomatique, Juillet 2017. https://www.monde-diplomatique.fr/cartes/pollution-chine, s.6 ; Pitron, G. (2017, July). Essor d'une écologie militante en Chine. Le Monde Diplomatique, Juillet 2017. https://www.mondediplomatique.fr/2017/07/PITRON/57676, s.6 ; Ayrica bkz. Rohde, R. A., \& Muller, R. A. (2015). Air Pollution in China: Mapping of Concentrations and Sources. PLOS ONE, 10(8), 1-14. https://doi.org/10.1371/journal.pone.0135749, s.2

Harita 4. Çin'de Hava Kirliliğinin Olduğu Kritik Merkezler (2015)

Küresel ısınmaya da yol açan hava kirliliği, aynı zamanda insan sağlığı üzerinde de olumsuz ve ölümcül etkileri bulunmaktadır. Hava kirliliği, gelişmekte olan ülkelerde önemli bir problem olup bu problemin AIDS, sitma, göğüs kanseri ve tüberkülozdan ${ }^{4}$ daha fazla insanı öldürdüğüne inanılmaktadır. Hava kirliğinde bulunan kimyasal parçacıkların her yıl 3 ile 7 milyon insanın ölümüne yol açtığı ve bu kalp solunum problemleri yarattığı tahmin edilmektedir (Rohde \& Muller, 2015: 1).

\section{AVRUPA BÖLGESI ISI ANORMALLİĞI SORUNU: İÇİLBİLIR SUYUN AZALMASI}

Küresel sorun olan 1S1 anormalliğinin Avrupa kıtası üzerindeki etkisi öncelikle içilebilir suyun azalması ve yıkanma amaçlı su kalitesinin bozulması olmaktadır. Ancak bu sorununun sadece Avrupa'da olduğu düşünülmemelidir. Dünya nüfusunun üçte biri içme suyundan mahrumdur (“De l'eau et de l'énergie," 2005:37). Dolayısılla, su kıtlığı problemi

\footnotetext{
${ }^{4}$ Bu hastalıkların arasına, günümüzün ölümcül salgını olan Covid-19 da eklenebilir.
} 
hem dünyanın hem de Avrupa'nın en büyük sıkıntısını teşkil etmektedir. Küresel 1sınma hidrolojik döngüler yaratarak sosyo-ekonomik olarak büyük rahatsıllıklar yaratacağ gibi, nüfusun ve nüfus yoğunluğunun çoğalmasıyla birlikte 2050 yılında dünya nüfusunun neredeyse \%40'ının su kitlığından doğrudan etkilenecektir (Laimé, 2008c). Avrupa'da su kıtlığı problemi ve bu probleme karşı eylem planları en önemli öncelikli sosyoekonomik ve çevre stratejileri arasında bulunmaktadır.

“...29 Ocak 2008 tarihinde, Avrupa Parlamentosu'nun iklim değişikliği geçici komitesinin 4. tematik oturumu sirasında, Avrupa Parlamentosu üyeleri ve uzmanlar arasındaki tartışmalar küresel ısınma ile küresel su kaynaklarının yönetimi arasındaki bağlantılar üzerinde yoğunlaşmıştır...” (Laimé, 2008b).

Avrupa Birliği’nin iklim değişikliğinde kaynaklı su eksikliği ve kuraklık problemi en önemli çözmesi gereken problemlerden birisidir (Laimé, 2008b).

Avrupa'nın diğer bir önceliği de Avrupa Birliği kriterleri kapsamında, suyun sadece içilebilir olması değil hava ve çevre kirliliği tehdidine karşı sudaki kimyasalların düşük tutulması ve kaliteli içme ve kullanım suyunun dağıtımıdır. Bu çerçevede, musluk suyundaki nitrat seviyesinin litrede 50 miligram (mg/l) (Laimé, 2008a) ve 2003 yılından 2008 y1lına kadar sudaki maksimum kurşun yoğunluğunun litrede $25 \mu \mathrm{g} / \mathrm{l}$ olmasına çalışılmış ve bu oranın 2013 yıl sonu itibariyle litrede $10 \mu \mathrm{g}$ olması hedeflenmiştir (Laimé, 2008d).

Daha on yıl öncesine kadar yapılan ölçümlerde, Avrupa nüfusunun \%17'sinin su azlığ 1 problemine maruz kaldığı ve bu oranın tedbir alınmadığı takdirde 2070 yılında \%35'i geçeceği vurgulanmıştır. Örneğin, 2003 yılında Avrupa'da meydana gelen kuraklık 8-9 milyarlık euro' luk bir zarar meydana getirmiş ve dolayısıyla Avrupa nüfusunun üçte biri, 100 milyondan fazla insan bu kuraklıktan etkilenmiştir. Son 30 yıl içinde, kuraklığın Avrupa Birliği'ne verdiği kayıp ise 100 milyar euro'dur (Laimé, 2008b). Avrupa'da 1s1 anormalliği, 2000 yılı mayıs ayında $+1,48^{\circ} \mathrm{C}, 2001^{\prime} \mathrm{de}+0,79^{\circ} \mathrm{C}, 2002^{\prime} \mathrm{de}+0,79^{\circ} \mathrm{C}$ ve kuraklığın yaşandığ 2003 'te ise $+2,01{ }^{\circ} \mathrm{C}$ dereceye ulaşmıştır (Climate at a Glance, Global Time Series, National Centers for Environmental Information (NCEI), 2020).

Grafik 6 ve Tablo 3 verilerinde görüldüğü gibi, 2005 yılında, $+0,82^{\circ} \mathrm{C}$ olan 1 s1 anormalliği 2007 ve 2012 yıllarında $+1,50^{\circ} \mathrm{C}^{\prime}$ in üzerinde seyrederken, 2018 yılında rekor seviye olan $+2,91^{\circ} \mathrm{C}$ 'a kadar ulaşmıştır. 2019 ve 2020 yıllarında ise, $+0,55^{\circ} \mathrm{C}$ ve $+0,45^{\circ} \mathrm{C}$ derecelerine inmiştir. $\mathrm{Bu}$ inişler $1 \mathrm{~s} 1$ düzelmelerinden çok $1 \mathrm{~S} 1$ dengesizliklerine bağlı görünmektedir. Bununla beraber, 1sı anormalliğinin 2020 Mayıs ayında $+0,45^{\circ} \mathrm{C}$ civarında olmasının nedeni 2020 Mart ayından beri Avrupa'nın Covid-19 salgını dolayısıyla karantinaya girmesi ve daha az taşıt kullanımı ve sanayi üretimine bağlı olarak daha az sera gazı emisyonundan kaynaklı olabilir (Cohan, 2020). 


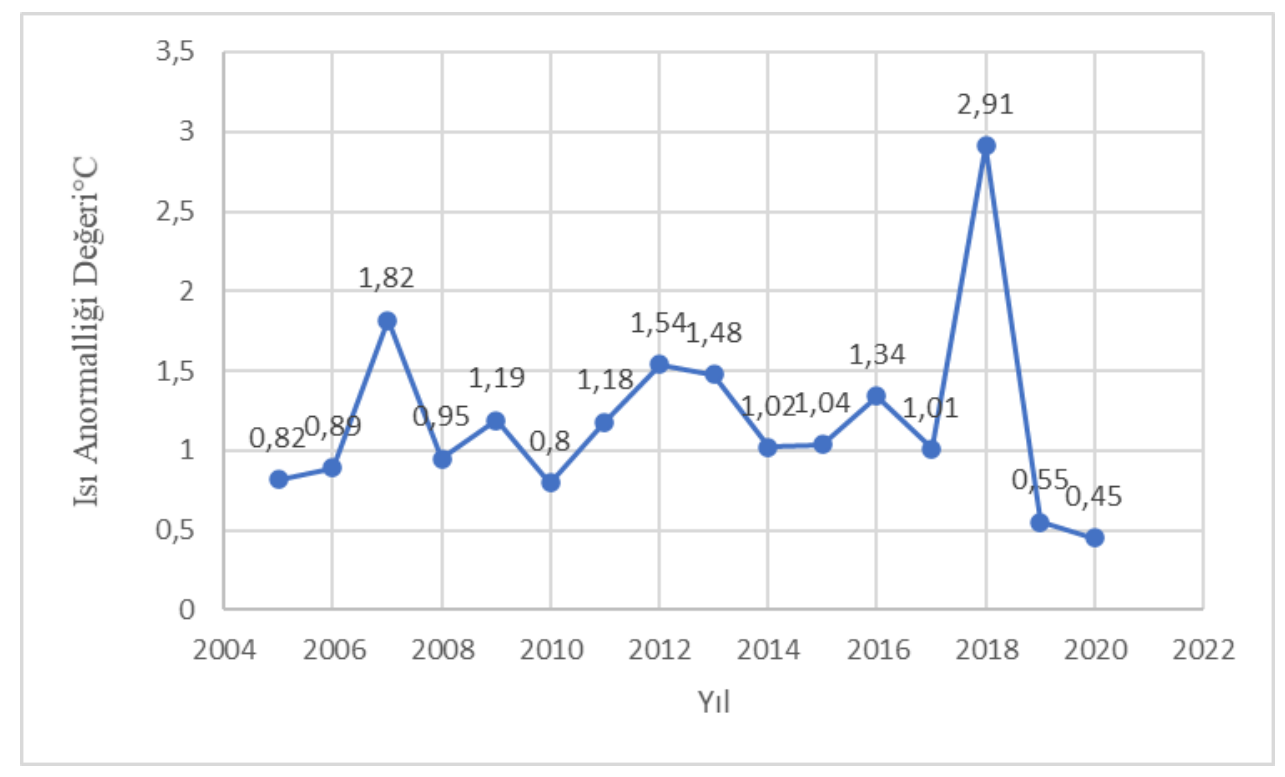

Kaynak:_Climate at a Glance | National Centers for Environmental Information (NCEI). (2020, July 8). NOAA https://www.ncdc.noaa.gov/cag/global/time-series/europe/land/1/5/2005-

2020 ?trend=true \&trend base $=10 \&$ begtrendyear $=2000 \&$ endtrendyear $=2020 \&$ filter $=$ true $\&$ filter $T y p e=$ binomial 'den elde edilen veriler ile çizilmiştir.

Grafik 6. 2005-2020 Yılları Arasında Avrupa Kıtası Isı Anormalliği ( $\left.{ }^{\circ} \mathrm{C}\right)$ (Mayıs)

Tablo 3. 2005-2020 Y1lları Arasında Avrupa Kıtası Isı Anormalliği ( $\left.{ }^{\circ} \mathrm{C}\right)$ (Mayıs)

\begin{tabular}{|cc|}
\hline Yll & Değer \\
\hline 2005 & 0,82 \\
\hline 2006 & 0,89 \\
\hline 2007 & 1,82 \\
\hline 2008 & 0,95 \\
\hline 2009 & 1,19 \\
\hline 2010 & 0,8 \\
\hline 2011 & 1,18 \\
\hline 2012 & 1,54 \\
\hline 2013 & 1,48 \\
\hline 2014 & 1,02 \\
\hline 2015 & 1,04 \\
\hline 2016 & 1,34 \\
\hline 2017 & 1,01 \\
\hline 2018 & 2,91 \\
\hline 2019 & 0,55 \\
\hline 2020 & 0,45 \\
\hline
\end{tabular}

Kaynak: Climate at a Glance | National Centers for Environmental Information (NCEI). (2020, July 8). NOAA https://www.ncdc.noaa.gov/cag/global/time-series/europe/land/1/5/2005-

2020 ?trend $=$ true \&trend base $=10 \&$ begtrendyear $=2000 \&$ endtrendyear $=2020 \&$ filter $=$ true \& filterType $=$ binomial 'den elde edilen veriler ile çizilmiştir. 


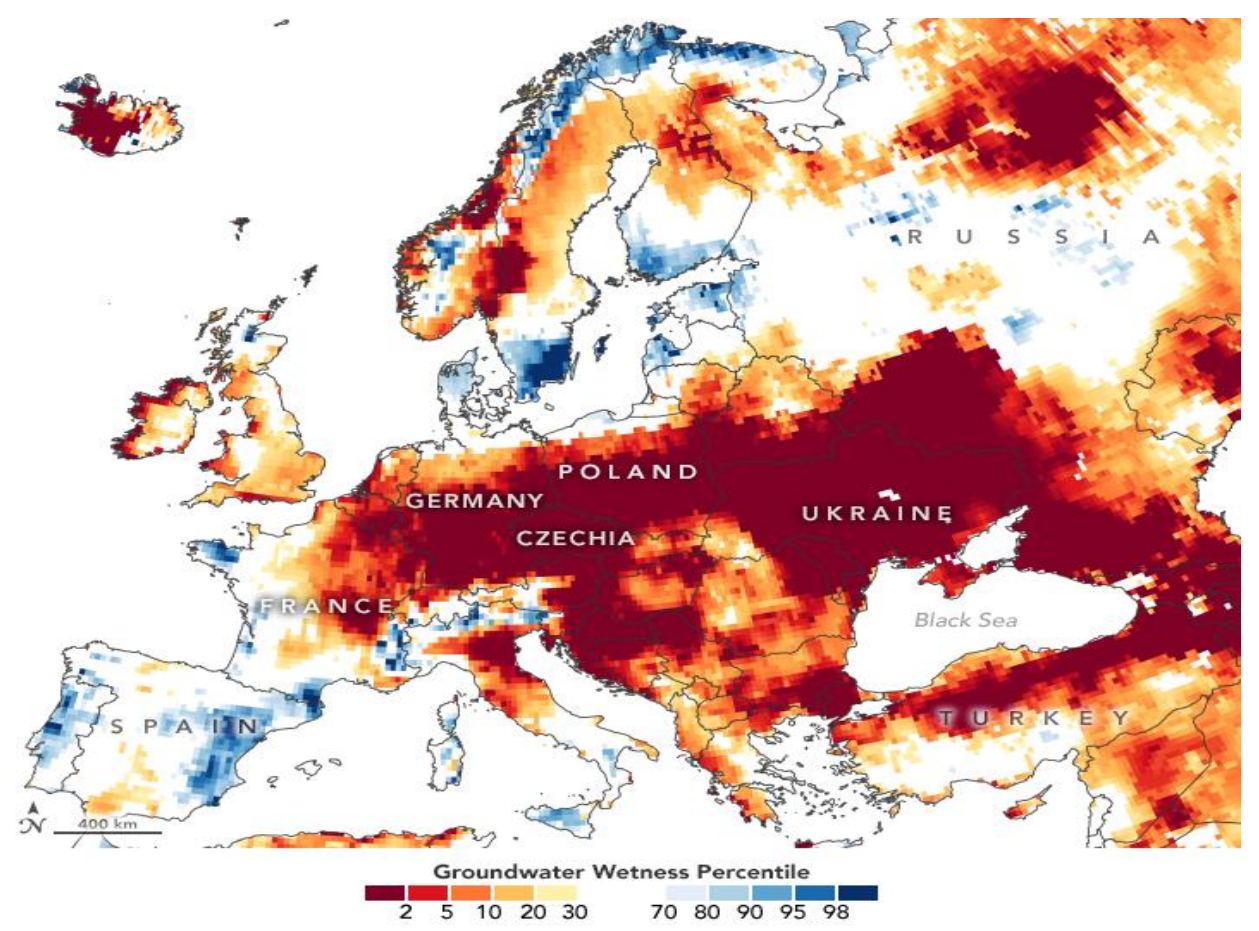

Kaynak: Signs of Drought in European Groundwater ( June 22, 2020). (2020, July 10). Earth Observatory. https://earthobservatory.nasa.gov/images/146888/signs-of-drought-in-european-groundwater

Harita 5. Avrupa Yeraltı Sularındaki Kuraklık Belirtileri

Avrupa'daki 1Sı anormalliği aynı zamanda yeraltı sularının da azalmasına neden olmaktadır. Kopernik İklim Değişikliği Servisi (Copernicus Climate Change Service / C3S)'nin gözlemlerine göre, 2020 baharının başlarında Doğu Avrupa'da meteorolojik kuraklık koşulları başlamış ve bu durum nisan ve mayıs aylarında normalden daha kurak bir hava ile tüm kıta boyunca devam etmiştir. Örneğin, kuraklığın yarattığı olumsuzlar sonucu, Elbe, Warta ve Tuna gibi bazı kita nehirlerinin su seviyesi mevsimsel normallerinin altına inmiştir. Avrupa'da kuraklık mayıs ve haziran aylarının sonlarında, bazı bölgelerde şiddetli yağışlar ile toparlanmış olsa da 1sı sicaklığ 1 bakımından 2020 küresel rekorun en sicak yıllarından biri olarak sayılmaktadır (Signs of Drought in European Groundwater (June 22, 2020), 2020).

\section{KUZEY AMERİKA BÖLGESİ ISI ANORMALLİĞİ SORUNU}

ABD Ulusal İklim Değerlendirmesi (ABD Küresel Değişim Araştırma Programı) ${ }^{5}$ raporuna göre, $\mathrm{ABD}$ ortalama sicaklığg1, 1sı kayıtlarının tutulduğu 1895 yılından beri $1,3^{\circ} \mathrm{F}^{\prime}$ dan $1,9^{\circ} \mathrm{F}$ 'a yükselmiştir. $\mathrm{Bu}$ 1sı artışının en yoğun olduğu dönem ise 1970 yılından itibaren olan dönemdir. Son yıllarda ABD'de 1sı artışında en rekor seviyelere ulaştığı görülmektedir. Bu anormallik durumunun daha da devam etmesi beklenmektedir (Climate Change Impacts in the United States : Climate Trends and Regional Impacts, 2014 : 2). Harita 6'da görüldüğü gibi, bir kıta ülkesi olan ABD'de 1sı anormalliği açık bir şekilde görülmektedir. Yine aynı şekilde Grafik 7 ve Tablo 4'te 2005-2020 yılları arasında yaşanan biyoçeşitliliği ve ekolojik dengeyi etkileyen 1s1 anormalliğinin kademeli artış değerleri görülmektedir. NOAA'nın verilerine göre, 2005 yılında $0,60^{\circ} \mathrm{C}$ ve 2020 yılın da $0,56^{\circ} \mathrm{C}$ olarak tespit edilmiştir. Isı anormalliğinin $1^{\circ} \mathrm{C}$ üzerine çıktığı yıllar $2012\left(1,41^{\circ} \mathrm{C}\right), 2015\left(1,09^{\circ} \mathrm{C}\right), 2016\left(1,35^{\circ} \mathrm{C}\right), 2017$ $\left(1,00^{\circ} \mathrm{C}\right)$ ve $2018\left(1,87^{\circ} \mathrm{C}\right)$ y1lları olarak görülmektedir (Grafik 7$)$.

\footnotetext{
${ }^{5}$ U.S. National Climate Assessment (U.S. Global Change Research Program)
} 


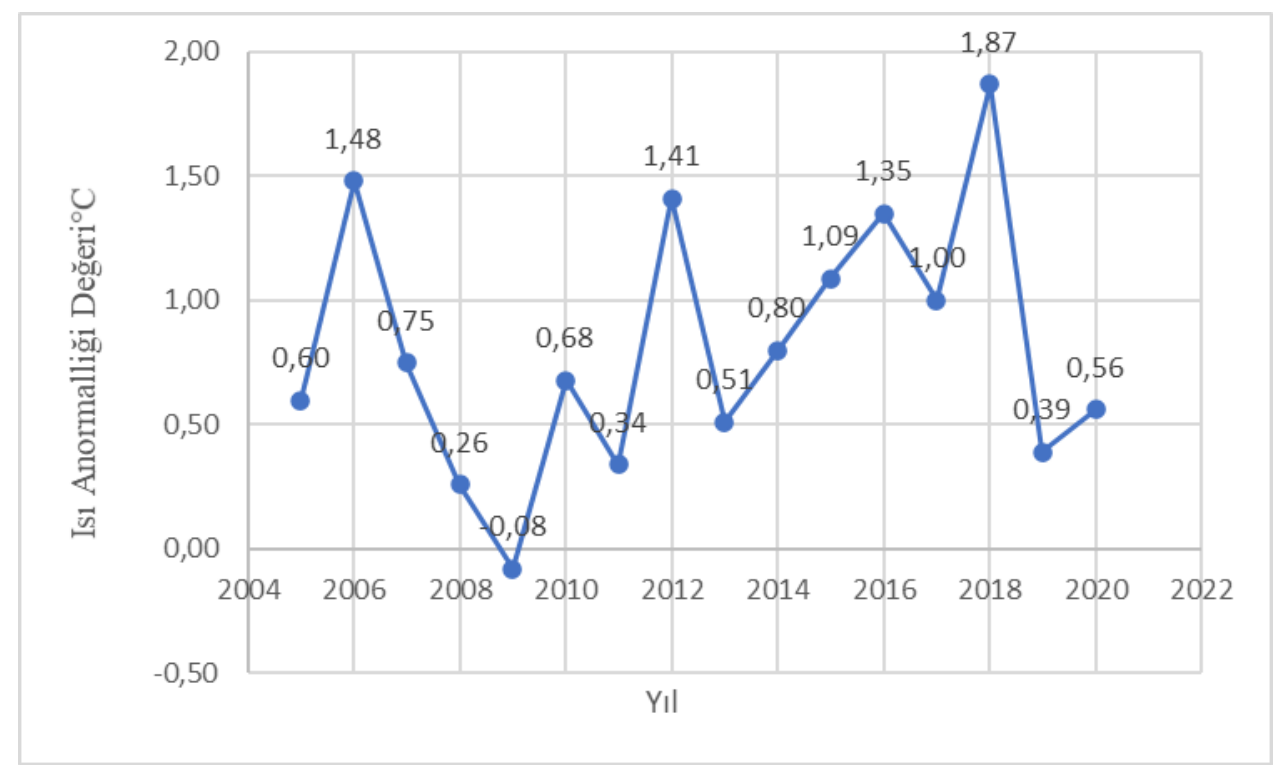

Kaynak: Climate at a Glance | National Centers for Environmental Information (NCEI). (2020, July 8). NOAA https://www.ncdc.noaa.gov/cag/global/time-series/northAmerica/land/1/5/2005-

2020?trend=true\&trend base $=10 \&$ begtrendyear $=2000 \&$ endtrendyear=2020\&filter $=$ true \&filterType=binomial 'den elde edilen veriler ile çizilmiştir.

Grafik 7. 2005-2020 Yılları Arasında Kuzey Amerika Kıtası Isı Anormalliği ( $\left.{ }^{\circ} \mathrm{C}\right)$ (Mayıs)

Tablo 4. 2005-2020 Yılları Arasında Kuzey Amerika Kıtası Isı Anormalliği ( $\left.{ }^{\circ} \mathrm{C}\right)$ (Mayıs)

\begin{tabular}{|l|l|}
\hline Yll & Değer \\
\hline 2005 & 0,60 \\
\hline 2006 & 1,48 \\
\hline 2007 & 0,75 \\
\hline 2008 & 0,26 \\
\hline 2009 & $-0,08$ \\
\hline 2010 & 0,68 \\
\hline 2011 & 0,34 \\
\hline 2012 & 1,41 \\
\hline 2013 & 0,51 \\
\hline 2014 & 0,80 \\
\hline 2015 & 1,09 \\
\hline 2016 & 1,35 \\
\hline 2017 & 1,00 \\
\hline 2018 & 1,87 \\
\hline 2019 & 0,39 \\
\hline 2020 & 0,56 \\
\hline
\end{tabular}

Kaynak: Climate at a Glance | National Centers for Environmental Information (NCEI). (2020, July 8). NOAA https://www.ncdc.noaa.gov/cag/global/time-series/northAmerica/land/1/5/2005-

$\underline{2020}$ ?trend=true \&trend base $=10 \&$ begtrendyear=2000\&endtrendyear $=2020 \&$ filter $=$ true $\&$ filterType $=$ binomial 'den elde edilen veriler ile çizilmiştir. 


\section{Observed U.S. Temperature Change}
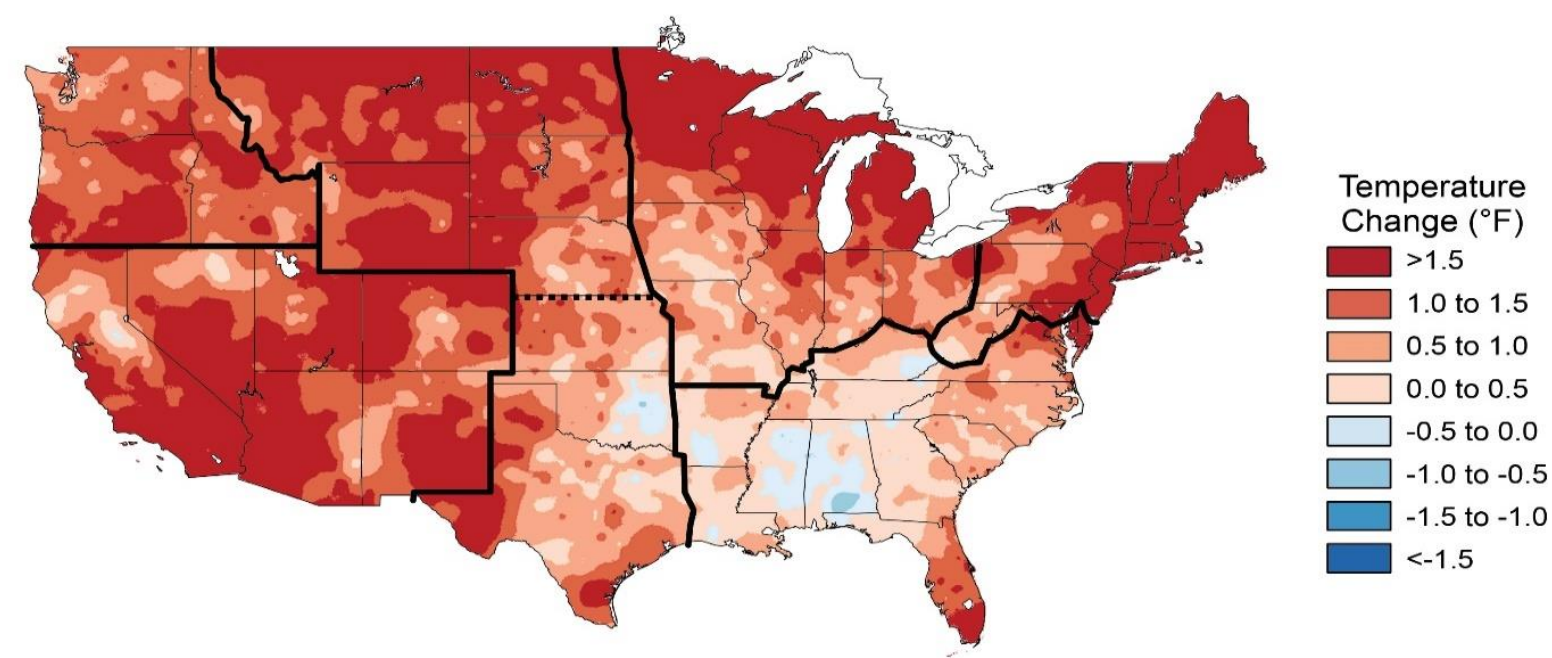

Kaynak: Climate Changes in the United States 1991-2012. (2020, July 11). NASA, Earth Observatory. https://earthobservatory.nasa.gov/images/83624/climate-changes-in-the-united-states

;https://eoimages.gsfc.nasa.gov/images/imagerecords/83000/83624/temperature_nca-1991-2012_lrg.jpg

Harita 6. ABD 1991-2012 Yılları Arası İklim Değişikliği Haritası

Isı anormalliğinin deniz seviyesinin Miami gibi kıyı şehirlerini tehdit etmesine, çölleşme yaratması ve su azlığı yaratmasına rağmen ABD uluslararası önlemlere katılma yerine kendi normlarını uygulama eğilimindedir. ABD Kyoto protokolünü zaten etki ve çerçevesini kaybettikten sonra en son onaylamış ve Trump başkanlığında Paris İklim Antlaşmasından ilk olarak Birleşmiş Milletleri çekilme niyeti hakkında bilgilendirerek (Paris climate accords: US notifies UN of intention to withdraw - BBC News, 2019) 2019 y1linda resmen çekilmiştir (Green, 2019). Bu durum ise bir taraftan küresel ısınma sorununu yaşayan ABD'deki siyasi otoritelerin yine aynı duyarlılık ile hareket etmeyerek, öncelikli olarak sanayi ölçekli düşünerek uluslararası gerekli önlemleri gelecek nesiller için almaktan kaçınması ayrı bir çelişki yaratmaktadır. Oysa, ABD'de gözlenen ısı anormalliği probleminin ciddiyeti, Amerikan menşeli veriler, bilim adamları ve gözlem ve araştırma merkezleri tarafindan her zaman dile getirilmekte, önem ve ciddiyeti sorgulanmakta ve bilimsel olarak raporlanmaktadir.

\section{GÜNEY AMERIKKA BÖLGESİ ISI ANORMALLİĞİ SORUNU}

Isı anormalliğinin nedeni olan küresel ısınmada farklı sera gazlarının da etkisi olmaktadır. Bunlar içinde karbondioksit $(\mathrm{CO} 2)$ ve metan $(\mathrm{CH} 4)$ tek başına sorunun dörtte üçünden sorumlu bulunmaktadır (Rabourdin, 2007b \& Rabourdin, 2007:32).

$\mathrm{Bu}$ tür sera gazlarına karşı doğal çare olan dünyanın akciğerleri olan Amazonlar Güney Amerika'da bulunmaktadır. Amazon ormanları 2,6 milyon ${ }^{6}$ mi $^{2}$ yüzölçümü ile Brezilya, Bolivya, Peru, Kolombiya, Ekvator, Venezuela, Guyana, Surinam ve Fransiz Guyanası ülkelerini kaplamaktadır (Brazil and the Amazon Forest - Greenpeace USA, 2020). Amazon ormanlarının \%60'1 Brezilya havzasında bulunmaktadır. Isı anormalliğinden etkilenen Güney Amerika aynı zamanda gezegenin atmosferik karbon seviyelerini kontrol etmede önemli bir rol oynamaktadır. Amazon Havzası, fosil yakıtlarının yıllık küresel emisyonların on katından fazla olan yaklaşık 100 milyar metrik ton karbon depolamaktadır (Brazil and the Amazon

\footnotetext{
${ }^{6} 6,733,969 \mathrm{~km}^{2}$
} 
Forest - Greenpeace USA, 2020). Bu nedenle, Güney Amerika küresel bir sensor vazifesi görmektedir. Grafik 8 ve Tablo 5'te değerlerin ortaya koyduğu gibi, 1sı anormalliği yoğun orman alanına karşı Güney Amerika'yı bu küresel krizden muaf tutmamaktadır, aksine ormanlar kademeli olarak hem doğa hem de insan eli ile tahrip olurken 1s1 anormalliği belli seviyede devam ederek bölgesel tehdidini sürdürmektedir. Ayrıca işlev kaybına uğrayan ormanlar küresel boyutta, dünyanın akciğerleri olma rolü de kademeli olarak gelecek nesiller için olumsuz bir şekilde etkilenmektedir. 2005 y1lında $+0,91^{\circ} \mathrm{C}$ olan 1 s1 anormalliği 2020 yılında $+1,08^{\circ} \mathrm{C}$ olmuştur. Isı anormalliğ 2015 yılında $+1,37^{\circ} \mathrm{C}, 2017$ yılında $+1,31^{\circ} \mathrm{C}, 2018$ yılında $+1,05^{\circ} \mathrm{C}$ ve 2019 yılında $+1,26^{\circ} \mathrm{C}$ olarak en yüksek değerlere ulaşmıştır (Grafik 8).

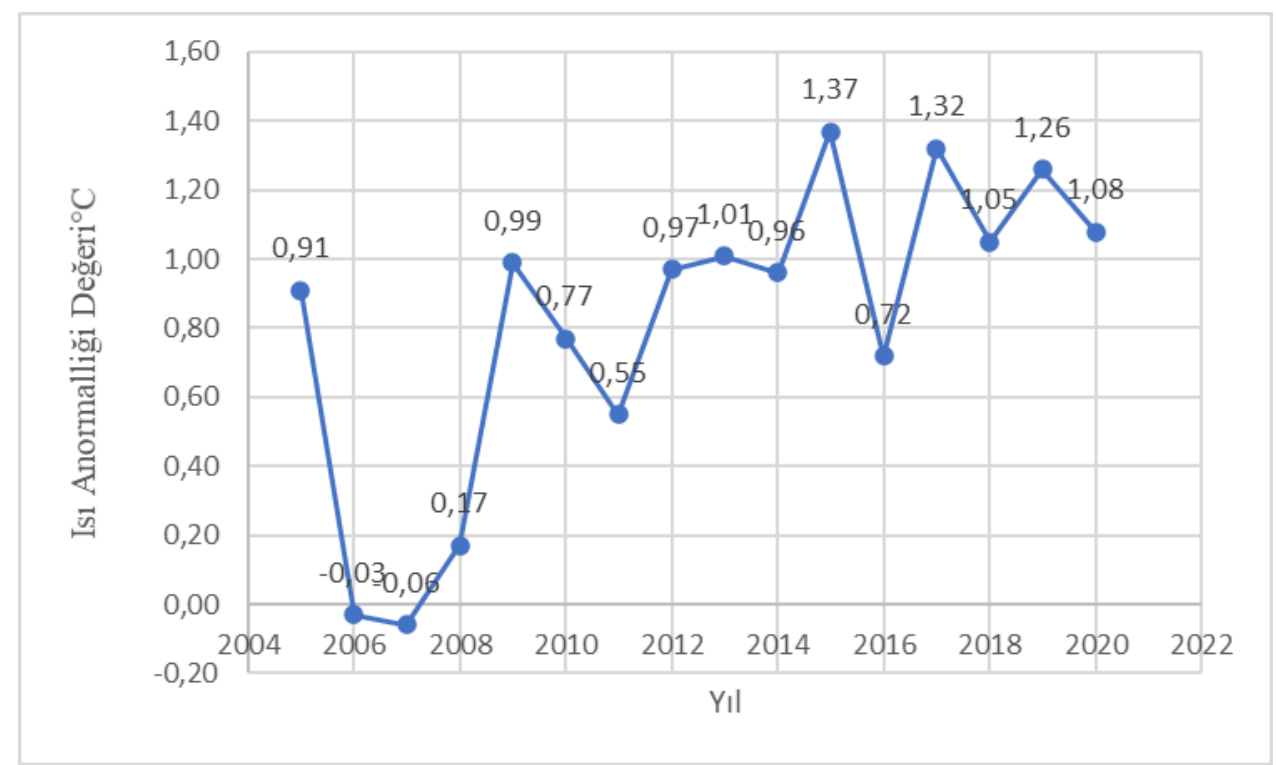

Kaynak: Climate at a Glance | National Centers for Environmental Information (NCEI). (2020, July 8). NOAA https://www.ncdc.noaa.gov/cag/global/time-series/southAmerica/land/1/5/2005-

2020?trend=true \&trend base $=10 \&$ begtrendyear $=2000 \&$ endtrendyear=2020\&filter $=$ true \&filterType $=$ binomial 'den elde edilen veriler ile çizilmiştir.

Grafik 8. 2005-2020 Yılları Arasında Güney Amerika Kıtası Isı Anormalliği ( $\left.{ }^{\circ} \mathrm{C}\right)$ (Mayıs) 
Tablo 5. 2005-2020 Yılları Arasında Güney Amerika Kıtası Isı Anormalliği $\left({ }^{\circ} \mathrm{C}\right)$ (Mayıs)

\begin{tabular}{|c|c|}
\hline Y1l & Değer \\
\hline 2005 & 0,91 \\
\hline 2006 & $-0,03$ \\
\hline 2007 & $-0,06$ \\
\hline 2008 & 0,17 \\
\hline 2009 & 0,99 \\
\hline 2010 & 0,77 \\
\hline 2011 & 0,55 \\
\hline 2012 & 0,97 \\
\hline 2013 & 1,01 \\
\hline 2014 & 0,96 \\
\hline 2015 & 1,37 \\
\hline 2016 & 0,72 \\
\hline 2017 & 1,32 \\
\hline 2018 & 1,05 \\
\hline 2019 & 1,26 \\
\hline$\underline{\mathbf{2 0 2 0}}$ & $\underline{\mathbf{1 , 0 8}}$ \\
\hline
\end{tabular}

Kaynak: Climate at a Glance | National Centers for Environmental Information (NCEI). (2020, July 8). NOAA https://www.ncdc.noaa.gov/cag/global/time-series/southAmerica/land/1/5/2005-

2020?trend=true\&trend_base $=10 \&$ begtrendyear $=2000 \&$ endtrendyear=2020\&filter $=$ true $\&$ filterType $=$ binomial 'den elde edilen veriler ile çizilmiştir.

\section{ISI ANORMALLİ̆İiNIN KÜRESEL FOTOĞRAFI}

Yukarıda çalışmanın sınırları kapsamında muaf tutulan bazı bölgeler (Pasifik, Avustralya, Kuzey Kutbu ve Güney Kutbu) dışında genel olarak incelenen Afrika, Asya, Avrupa, Kuzey Amerika ve Güney Amerika'da 1sı anormalliği sorununun küresel boyutta ne derece önemli bir problem olduğunu inceledikten sonra, en son olarak küresel alarm veren 1s1 anormalliği probleminin dünya boyutunda karşılaştırılması faydalı olacaktır. Bu karşılaşma Harita 7, Harita 8 ve Harita 9'un incelenmesinde açık bir şekilde görülmektedir.

Harita 71884 yılının küresel fotoğrafını sunmaktadır. 1884 yılında henüz bugünkü kadar vahim bir durumun olmadığı görülmektedir. 


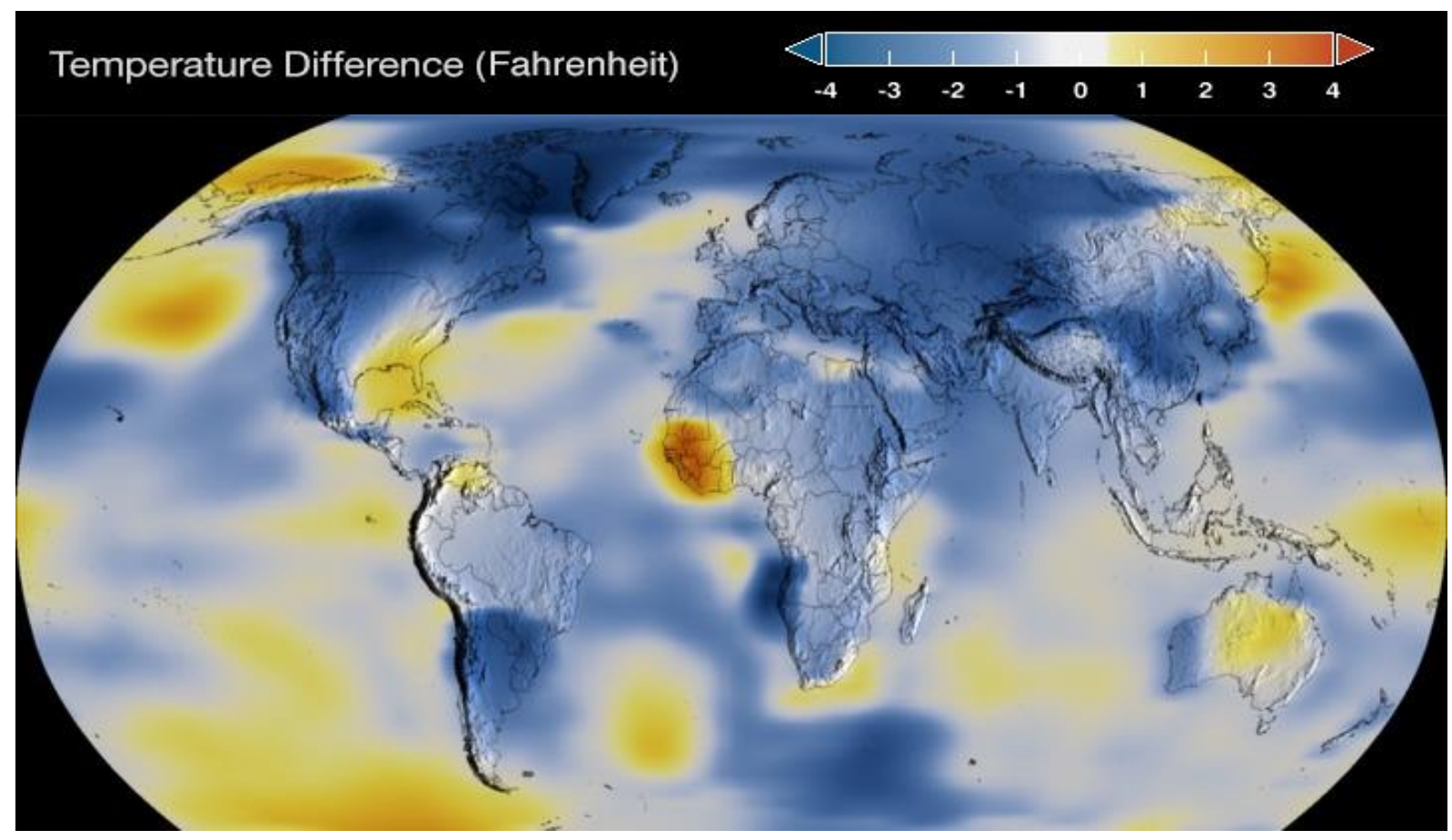

Kaynak: Global Temperature | Vital Signs - Climate Change: Vital Signs of the Planet: TIME SERIES: 1884 TO 2019. (2020, July 14). NASA, Global Climate Change. https://climate.nasa.gov/vital-signs/globaltemperature/

Harita 7. 1884 Y1lı Dünya Isı Anormalliği Durumu ( $\left.{ }^{\circ} \mathrm{F}\right)$

Harita 8'de Kuzey Kutbu ve Kuzey Sibirya bölgelerinde 1955 yılı açık bir şekilde gözlenen bir anormalliğin başladığg gözlenmektedir.

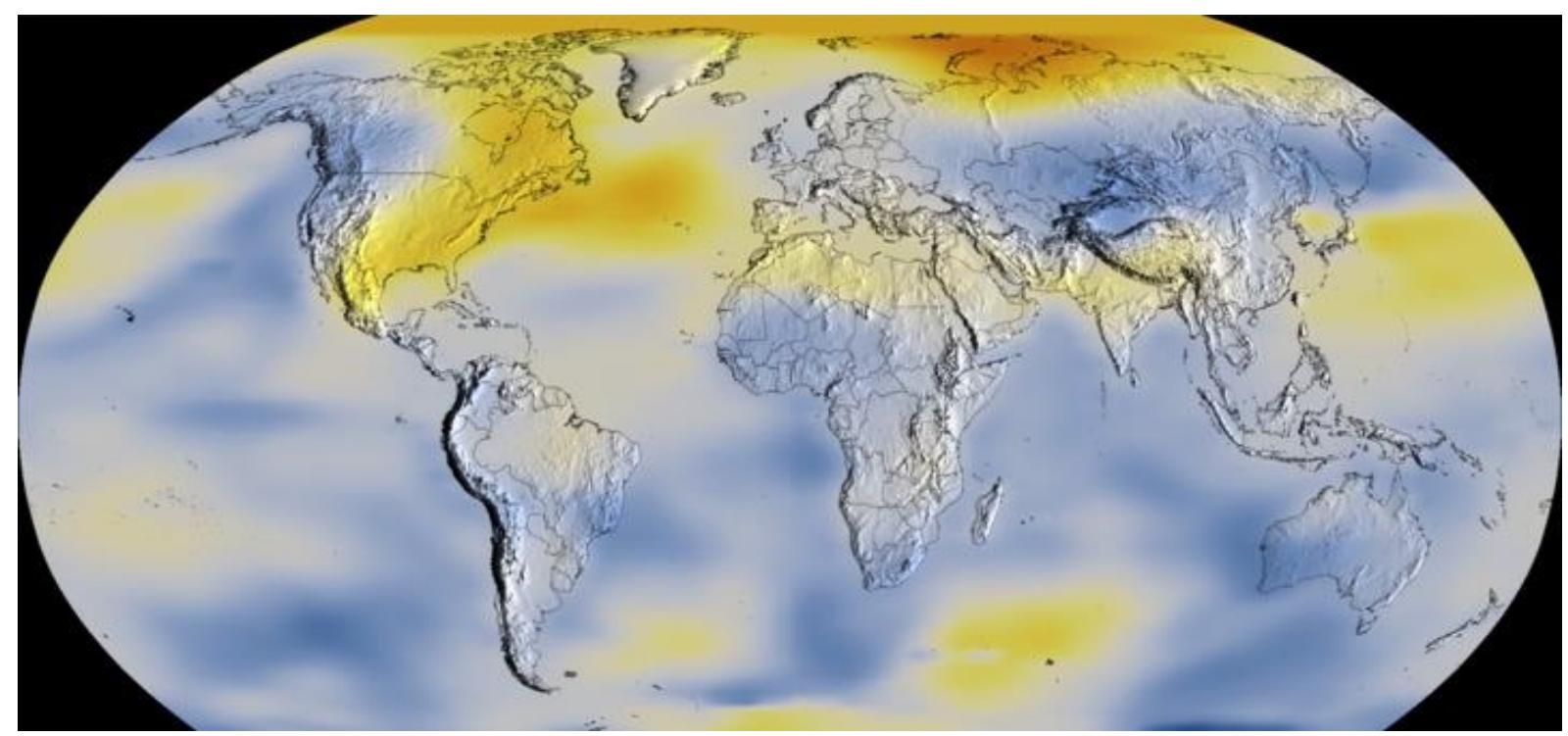

Kaynak: Global Temperature | Vital Signs - Climate Change: Vital Signs of the Planet: TIME SERIES: 1884 TO 2019. (2020, July 14). NASA, Global Climate Change. https://climate.nasa.gov/vital-signs/globaltemperature/

Harita 8. 1955 Y1lı Dünya Isı Anormalliği Durumu $\left({ }^{\circ} \mathrm{F}\right)$ 
Harita 9 ise 2019 yılında yaşanan vahim durumunun küresel durumunu göstermektedir.

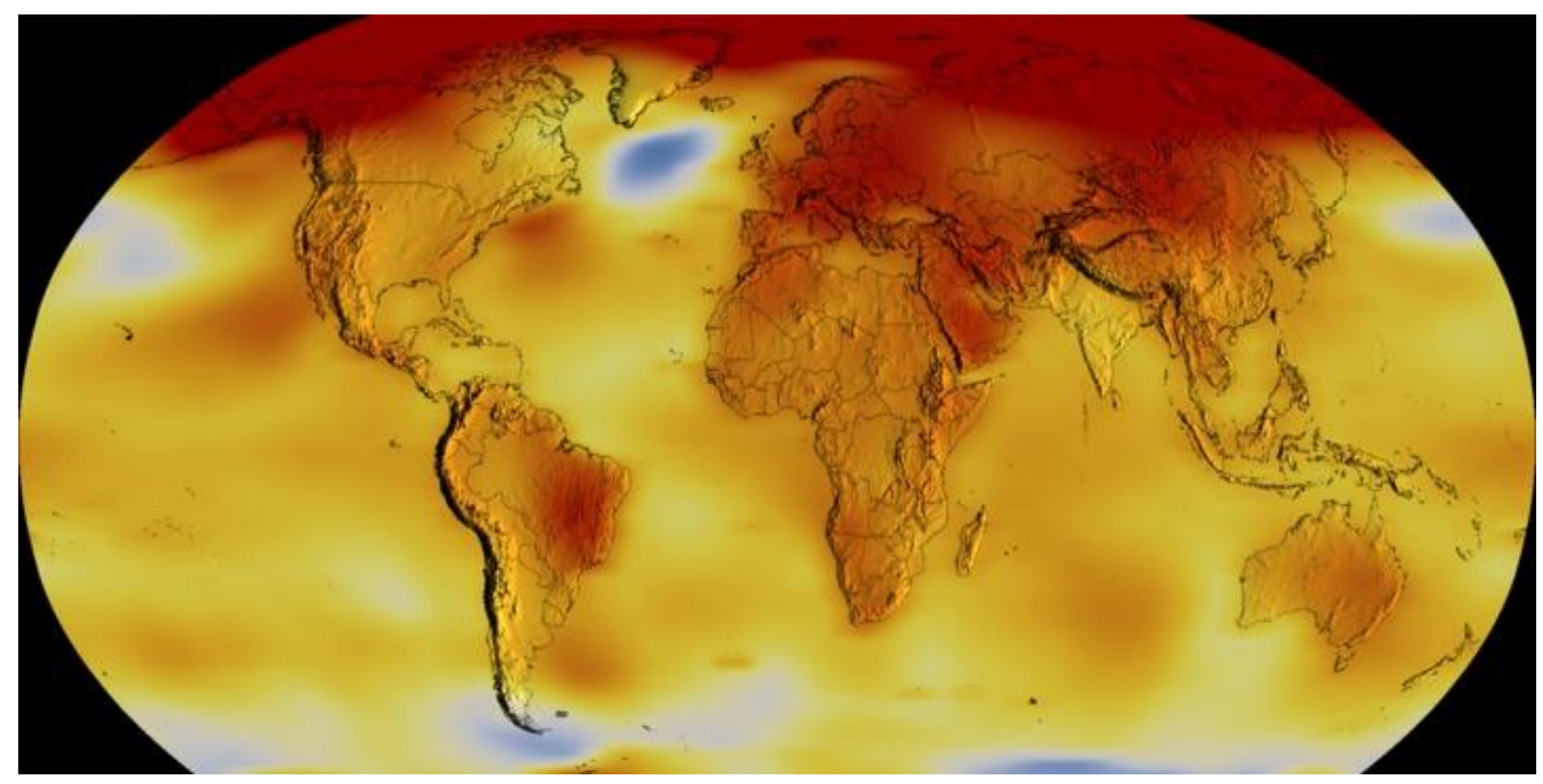

Kaynak: Global Temperature | Vital Signs - Climate Change: Vital Signs of the Planet: TIME SERIES: 1884 TO 2019. (2020, July 14). NASA, Global Climate Change. https://climate.nasa.gov/vital-signs/globaltemperature/

Harita 9. 2019 Y1lı Dünya Isı Anormalliği Durumu $\left({ }^{\circ} \mathrm{F}\right)$

\section{SONUÇ}

Etkileri somut ve fiziksel olarak görünen 1sı anormalliği problemi makro düzeyde dünyanın ve mikro düzeyde ise her ülkenin etkisini yaşadığı ve olumsuzluklarını yakın, orta ve uzun gelecekte felaket ve trajik boyutlarında yaşayacağı bir uluslararası ve ulusal güvenlik fenomenidir. Isı anormalliğinin neden olduğu ve olacağı çölleşme, su kıtlığı, deniz seviyelerinin yükselmesine bağlı bölgesel ve uluslararası göçlerin yaşanması senaryosunu içinde barındıran bu güvenlik problemi aynı zamanda tüm bu problemlere bağlı silahlı çatışmaları da tetikleme potansiyeline sahiptir. Önlem alınmadığı ve gerekli tedbirler eşit seviyede ve eş zamanda uygulamaya konulmadığı takdirde, yakın gelecekte, "jeopolitik önem" ve "jeopolitik konum" kavramları, 1sı anormalliğinin, deniz suyu yükselme seviyesinin az olduğu ve içme ve kullanma sularının ve ekilebilir tarım arazilerinin daha çok olduğu bölgeler için geçerli kavramlar olacaktır.

İklim değişikliği ve 1sı anormalliği problemleri küresel boyutta dünyada çölleşmeye dolayısıyla tarım alanlarının azalmasına, su kıtlığına, Bangladeş örneğinde olduğu gibi iç ve bölgesel göçlere ve Sahra örneğinde olduğu gibi verimli arazilerin paylaşımı için silahlı çatışmaların yaşanmasına neden olmaktadır.

Is1 anormalliğinin getirdiği diğer bir doğal olumsuzluk ise buzulların erimesi sonucu kıyı şeritlerinin ve önemli yerleşim birimlerinin su altında kalacak olmasıdır. Tehdidi sadece bu olumsuzluklar ile sınırlı kalmayan ısı anormalliği (iklim değişikliği), biyoçeşitliliği (bitki ve hayvan), ekolojik dengesini bozmakta ve çölleşme ile küresel boyutta küresel açlığın daha da artmasina neden olmaktadir.

Is1 anormalliğinin önlenmesi sivil toplum kuruluşlarının ve bireylerin duyarlılığı ve seferberliğinden öte özellikle gelişmekte olan ülkelere oranla iklim değişikliğinde teknolojik 
ve sanayi üstünlükleri veya kullanım kapasiteleri atmosfere yaydıkları sera gazları ile pay sahibi sorumlu ülkelerin, alınacak tedbirleri ödün vermeden uygulamalarıyla mümkün olacaktır. Aksi takdirde, uzay çağını yaşayan dünya ülkeleri, bir taraftan uzaya erişme teknolojisini elinde tutarken, diğer taraftan yaşadığı dünya üzerindeki jeo-sosyolojik, jeoekonomik ve jeo-politik güç hakimiyetlerini kaybedeceklerdir.

Dünya güvenliğini tehdit eden küresel ısınma probleminin önlem alınmadığı takdirde gelecekte kontrol altına alınması zor görünmektedir. Bu nedenle, küresel ısınmayı tetikleyen küresel 1sı anormalliğinin bir küresel güvenlik problemi olarak kabul edilmesi ve hızlı ve acil olarak gerekli önlemlerin alınması şimdiki nesillerin yaşam kalitesinin sağlanması ve gelecek nesillerin devamlılığı açısından zorunlu bulunmaktadır.

\section{KAYNAKÇA}

Africa|Action Against Desertification |Food and Agriculture Organization of the United Nations. (2020). FAO. http://www.fao.org/in-action/action-againstdesertification/countries/africa/en/

Bafana, B. . (2017, June 15). The High Price of Desertification: 23 Hectares of Land a Minute - World | ReliefWeb. https://reliefweb.int/report/world/high-pricedesertification-23-hectares-land-minute

Birth rate, crude (per 1,000 people) | Data. (2020, July 5). The World Bank. https://data.worldbank.org/indicator/SP.DYN.CBRT.IN

Bonneuil, C. (2015, November). Tous responsables du dérèglement climatique? Le Monde Diplomatique, Novembre 2015. https://www.mondediplomatique.fr/2015/11/BONNEUIL/54139

Brazil and the Amazon Forest - Greenpeace USA. (2020, July). Green Peace. https://www.greenpeace.org/usa/issues/brazil-and-the-amazon-forest/

Burke, M. B., Miguel, E., Satyanath, S., Dykema, J. A., \& Lobell, D. B. (2009). Warming increases the risk of civil war in Africa. Proceedings of the National Academy of Sciences of the United States of America, 106(49), 20670-20674. https://doi.org/10.1073/pnas.0907998106

Climate at a Glance | National Centers for Environmental Information (NCEI). (2020, July 6). NOAA. https://www.ncdc.noaa.gov/cag/global/time-series/globe/land/1/5/20002020 ?trend=true \&trend base $=10 \&$ begtrendyear $=2000 \&$ endtrendyear $=2020 \&$ filter $=$ tru e\&filterType=binomial

Climate at a Glance, Global Time Series, National Centers for Environmental Information (NCEI). (2020, July 10). NOAA. https://www.ncdc.noaa.gov/cag/global/timeseries/europe/land/1/5/2000-

2020?trend=true \&trend base $=10 \&$ begtrendyear $=2000 \&$ endtrendyear $=2020 \&$ filter $=$ tru e\&filterType=binomial

Climate Changes in the United States 1991-2012. (2020, July 11). NASA, Earth Observatory. https://earthobservatory.nasa.gov/images/83624/climate-changes-in-the-united-states ; https://eoimages.gsfc.nasa.gov/images/imagerecords/83000/83624/temperature_nca1991-2012_lrg.jpg

Climate Change Impacts in the United States : Climate Trends and Regional Impacts. (2014). https://www.globalchange.gov/sites/globalchange/files/NCA3-climate-trends-regionalimpacts-brochure.pdf 
Cohan, D. (2020, April 17). COVID-19 shutdowns are clearing the air, but pollution will return as economies reopen. Theconversation.Com. https://theconversation.com/covid-19-shutdowns-are-clearing-the-air-but-pollutionwill-return-as-economies-reopen-134610

Death rate, crude (per 1,000 people) | Data. (2020, July 5). The World Bank. https://data.worldbank.org/indicator/SP.DYN.CDRT.IN

De l'eau et de l'énergie. (2005). Manière de Voir, 81(Juin-Juillet), 37.

Garnier, D. (2007, April). Au Bangladesh, les premiers réfugiés climatiques. Le Monde Diplomatique, Avril $2007 . \quad \underline{\text { https://www.monde- }}$ diplomatique.fr/2007/04/GARNIER/14594

Global Temperature, NASA: Climate Change and Global Warmings. (2020, July 5). NASA. https://climate.nasa.gov/vital-signs/global-temperature/

Green, F. J. (2019, October 30). Trump is officially withdrawing from the Paris climate agreement. That won't change much. - The Washington Post. The Washington Post. https://www.washingtonpost.com/politics/2019/10/30/trumps-officially-withdrawingparis-climate-agreement-that-wont-change-much/

Helldén, U., \& Tottrup, C. (2008). Regional desertification: A global synthesis. Global and Planetary Change, 64(3-4), 169-176. https://doi.org/10.1016/j.gloplacha.2008.10.006

King, E. (Editor). (2013, April 19). Desertification Crisis Affecting 168 Countries Worldwide, Study Shows - Our World. Our World . https://ourworld.unu.edu/en/desertificationcrisis-affecting-168-countries-worldwide-study-shows

Laimé, M. (2008a), (2008, April 3). L'Europe de l'eau (1): mobilisation durable ou balkanisation? Les Blogs Du Monde Diplomatique . https://blog.mondediplo.net/2008-04-03-L-Europe-de-1-eau-1-mobilisation-durable-ou

Laimé, M. (2008b), (2008, April 12). L'Europe de l'eau (2): faire face au changement climatique. Les Blogs du Monde Diplomatique. https://blog.mondediplo.net/2008-0412-L-Europe-de-1-eau-2-faire-face-au-changement

Laimé, M. (2008c), (2008, April 21). L'Europe de l'eau (3) : la fuite en avant? Les Blogs du Monde Diplomatique. https://blog.mondediplo.net/2008-04-21-L-Europe-de-1-eau-3la-fuite-en-avant

Laimé, M. (2008d), (2008, April 30). L'Europe de l'eau (4): quel avenir pour le service public? Les Blogs Du Monde Diplomatique. https://blog.mondediplo.net/2008-04-30L-Europe-de-1-eau-4-quel-avenir-pour-le-service

Marin, C. (2017, July). Niveaux extrêmes de pollution en Chine. Le Monde Diplomatique, Juillet 2017. https://www.monde-diplomatique.fr/cartes/pollution-chine

Martin, E. (2015, November). Deux degrés de plus, deux degrés de trop. Le Monde Diplomatique, Novembre 2015. https://www.monde-diplomatique.fr/2015/11/MARTIN/54201

Paris climate accords: US notifies UN of intention to withdraw - BBC News. (2019, November 5). BBC News. https://www.bbc.com/news/world-us-canada-50297029

Pitron, G. (2017, July). Essor d'une écologie militante en Chine. Le Monde Diplomatique, Juillet 2017. https://www.monde-diplomatique.fr/2017/07/PITRON/57676 
Population 2019. (2020, July 5). The World Bank. https://databank.worldbank.org/data/download/POP.pdf

Population growth (annual \%) | Data. (2020, July 5). The World Bank. https://data.worldbank.org/indicator/SP.POP.GROW

Rabourdin, S. (2007). Le changement climatique perturbe le cycle du carbone. L'Atlas Environnement : Analyses et Solutions (Le Monde Diplomatique, 2007). https://www.monde-diplomatique.fr/publications/1_atlas_environnement/a53607

Rabourdin, S. (2007b). Le changement climatique perturbe le cycle du carbone. Le Monde Diplomatique.

https://www.monde-diplomatique.fr/publications/1_atlas_environnement/a53607

Ramonet, I. (Juin-Juillet 2005). Espoirs écologiques. Manière de Voire, Ecologie: Le Grand Défi (81), 6-8.

Satterthwaite, D. (2009). The implications of population growth and urbanization for climate change. https://www.uncclearn.org/sites/default/files/inventory/unfpa13.pdf

Signs of Drought in European Groundwater ( June 22, 2020). (2020, July 10). Earth Observatory. https://earthobservatory.nasa.gov/images/146888/signs-of-drought-ineuropean-groundwater

Silver, J. (2008). Global Warning \& Climate Change (Demystifie). McGraw Hill.

Sinaï, A. (2015, August). Aux origines climatiques des conflits. Le Monde Diplomatique, Août 2015. https://www.monde-diplomatique.fr/2015/08/SINAI/53507

Stratégie Régionale harmonisée de mise en oeuvre de l'initiative "Grande muraille verte pour le Sahara et le Sahel». (n.d.). Retrieved July 9, 2020, from http://www.fao.org/3/a-av133f.pdf 